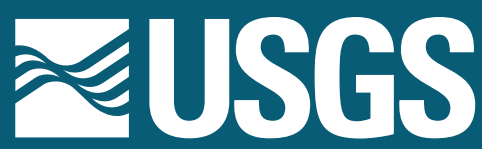

science for a changing world

Prepared in cooperation with the Muskingum Watershed Conservancy District

\title{
An Analysis of Potential Water Availability from the Atwood, Leesville, and Tappan Lakes in the Muskingum River Watershed, Ohio
}

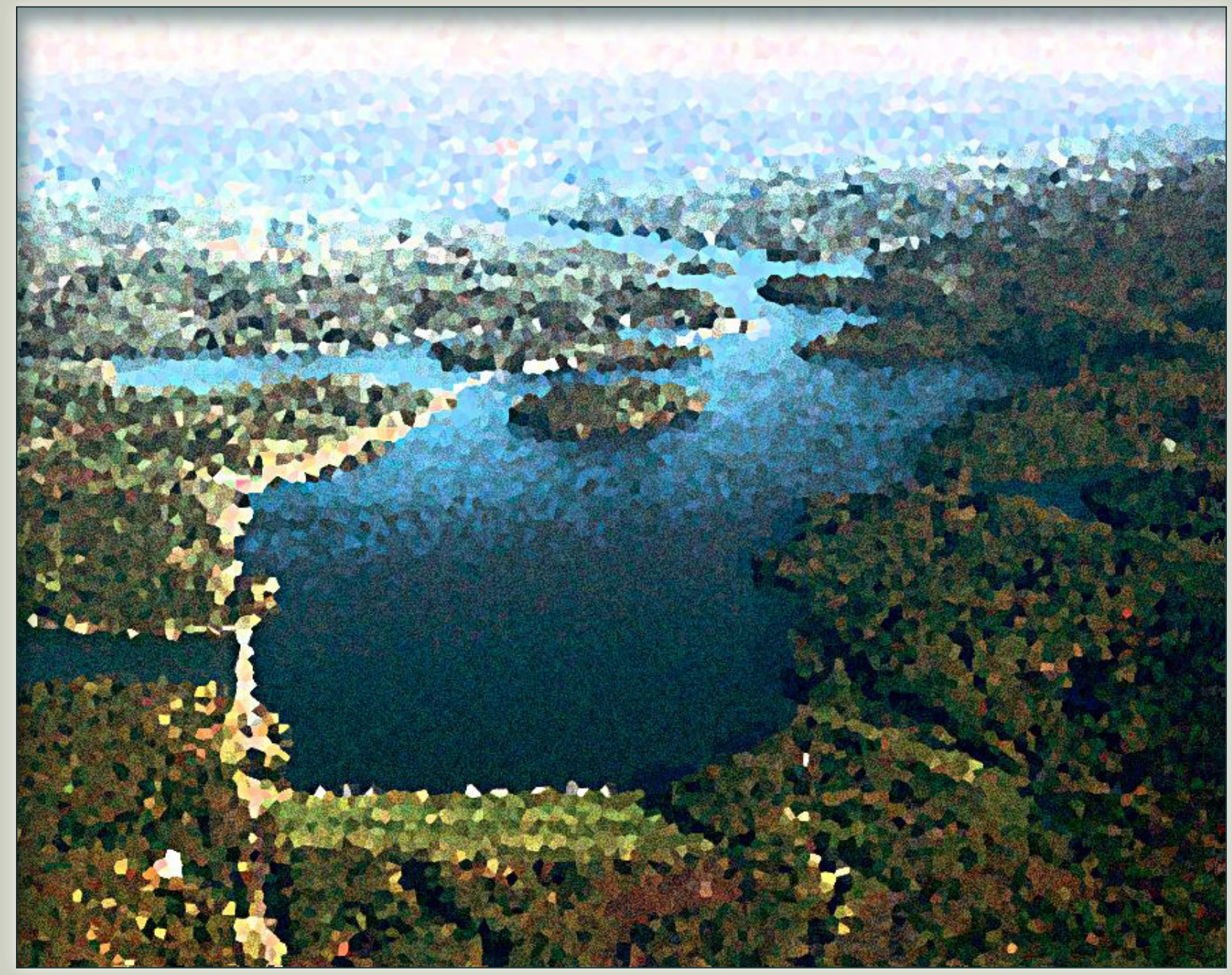

Scientific Investigations Report 2013-5112

Version 1.1, January 2014

U.S. Department of the Interior

U.S. Geological Survey 
Cover image. Aerial view of Tappan Lake in the Muskingum River Watershed, Ohio. Rendering based on original photograph provided by the Muskingum Watershed Conservancy District (used with permission). 


\section{An Analysis of Potential Water Availability from the Atwood, Leesville, and Tappan Lakes in the Muskingum River Watershed, Ohio}

By G.F. Koltun

Prepared in cooperation with the Muskingum Watershed Conservancy District

Scientific Investigations Report 2013-5112

Version 1.1, January 2014 


\title{
U.S. Department of the Interior SALLY JEWELL, Secretary
}

\section{U.S. Geological Survey Suzette M. Kimball, Acting Director}

\author{
U.S. Geological Survey, Reston, Virginia: 2013 \\ Revised: January 2014
}

\begin{abstract}
For more information on the USGS - the Federal source for science about the Earth, its natural and living resources, natural hazards, and the environment, visit http://www.usgs.gov or call 1-888-ASK-USGS.

For an overview of USGS information products, including maps, imagery, and publications, visit http://www.usgs.gov/pubprod

To order this and other USGS information products, visit http://store.usgs.gov
\end{abstract}

Any use of trade, firm, or product names is for descriptive purposes only and does not imply endorsement by the U.S. Government.

Although this information product, for the most part, is in the public domain, it also may contain copyrighted materials as noted in the text. Permission to reproduce copyrighted items must be secured from the copyright owner.

Suggested citation:

Koltun, G.F., 2013, An analysis of potential water availability from the Atwood, Leesville, and Tappan Lakes in the Muskingum River Watershed, Ohio (ver. 1.1, January 2014): U.S. Geological Survey Scientific Investigations Report 2013-5112, 33 p.,Whttp://dx.doi.org/10.3133/sir20135112.

ISSN 2328-0328 (online) 


\section{Contents}

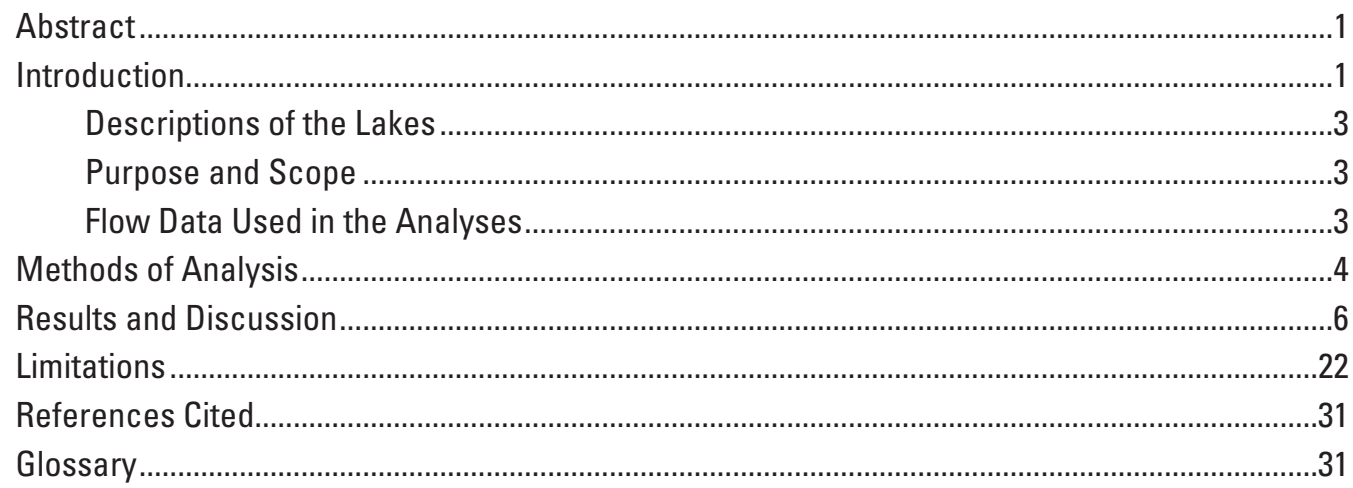

\section{Figures}

1. Map showing locations of lakes and streamgages in the Muskingum River Watershed, Ohio .....................................................................................2

2. Flowchart outlining the logic by which withdrawal and flow-by amounts

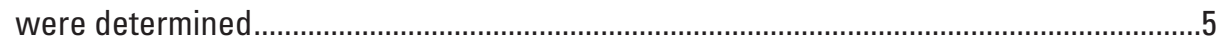

3. Graph showing surplus-water mass curves based on current target minimum outflows for the Atwood, Leesville, and Tappan Lakes in the Muskingum River Watershed, Ohio.....

\section{Tables}

1. U.S. Geological Survey streamgages and periods of gage record used in the water-availability analyses for the Muskingum River Watershed, Ohio ..................3

2. Statistics of calendar-year potential withdrawals for the Atwood, Leesville, and Tappan Lakes in the Muskingum River Watershed, Ohio.

3. Statistics of Atwood Lake, Ohio, total monthly potential withdrawals for indicated pumping rates and target minimum flow-by amounts.

4. Statistics of Leesville Lake, Ohio, total monthly potential withdrawals for indicated pumping rates and target minimum flow-by amounts.

5. Statistics of Tappan Lake, Ohio, total monthly potential withdrawals for indicated pumping rates and target minimum flow-by amounts.

6. Analytical period statistics of observed daily mean outflows from the Atwood, Leesville, and Tappan Lakes in the Muskingum River Watershed, Ohio.....

7. Statistics of observed daily mean outflows by month for the Atwood, Leesville, and Tappan Lakes in the Muskingum River Watershed, Ohio.

8. Statistics of daily mean flow-by amounts for indicated pumping rates and target minimum flow-by multiples for the Atwood, Leesville, and Tappan Lakes in the Muskingum River

9. Statistics of Atwood Lake, Ohio, daily mean flow-by amounts, by month, for indicated pumping rates and target minimum flow-by amounts.

10. Statistics of Leesville Lake, Ohio, daily mean flow-by amounts, by month, for indicated pumping rates and target minimum flow-by amounts 
11. Statistics of Tappan Lake, Ohio, daily mean flow-by amounts, by month, for indicated pumping rates and target minimum flow-by amounts.....

12. Daily mean flow-by statistics for the Atwood, Leesville, and Tappan Lakes, Muskingum River Watershed, Ohio, expressed as a percentage of observed outflow statistics.

13. Monthly statistics of Atwood Lake, Ohio, daily mean flow-by amounts for indicated pumping rates and target minimum flow-by amounts, expressed as a percentage of corresponding statistic based on observed outflows

14. Monthly statistics of Leesville Lake, Ohio, daily mean flow-by amounts for indicated pumping rates and target minimum flow-by amounts, expressed as a percentage of corresponding statistic based on observed outflows

15. Monthly statistics of Tappan Lake, Ohio, daily mean flow-by amounts for indicated pumping rates and target minimum flow-by amounts, expressed as a percentage of corresponding statistic based on observed outflows

\section{Appendix 1.}

1-1. Table of cumulative surplus water at the Atwood, Leesville, and Tappan Lakes as a function of target minimum flow-by amount. 


\section{Conversion Factors and Abbreviations}

\begin{tabular}{lcl}
\hline \multicolumn{1}{c}{ Multiply } & By & To obtain \\
\hline foot $(\mathrm{ft})$ & Length & meter $(\mathrm{m})$ \\
\hline & 0.3048 & \\
\hline square ${\mathrm{mile}\left(\mathrm{mi}^{2}\right)}^{\prime}$ & Area & hectare $(\mathrm{ha})$ \\
square mile $\left(\mathrm{mi}^{2}\right)$ & 259.0 & square kilometer $\left(\mathrm{km}^{2}\right)$ \\
\hline & 2.590 & \\
\hline million gallons $(\mathrm{Mgal})$ & Volume & cubic meter $\left(\mathrm{m}^{3}\right)$ \\
\hline & $3,785.0$ & \\
\hline cubic foot per second $(\mathrm{ft} / \mathrm{s})$ & Flow rate & cubic meter per second $\left(\mathrm{m}^{3} / \mathrm{s}\right)$ \\
million gallons per day $(\mathrm{Mgal} / \mathrm{d})$ & 0.02832 & cubic meter per second $\left(\mathrm{m}^{3} / \mathrm{s}\right)$ \\
\hline
\end{tabular}

\section{Abbreviations}

MWCD

SAS

USACE

USGS
Muskingum Watershed Conservancy District

Statistical Analysis System

U.S. Army Corps of Engineers

U.S. Geological Survey 



\title{
An Analysis of Potential Water Availability from the Atwood, Leesville, and Tappan Lakes in the Muskingum River Watershed, Ohio
}

\author{
By G.F. Koltun
}

\section{Abstract}

This report presents the results of a study to assess potential water availability from the Atwood, Leesville, and Tappan Lakes, located within the Muskingum River Watershed, Ohio. The assessment was based on the criterion that water withdrawals should not appreciably affect maintenance of recreation-season pool levels in current use. To facilitate and simplify the assessment, it was assumed that historical lake operations were successful in maintaining seasonal pool levels, and that any discharges from lakes constituted either water that was discharged to prevent exceeding seasonal pool levels or discharges intended to meet minimum in-stream flow targets downstream from the lakes. It further was assumed that the volume of water discharged in excess of the minimum in-stream flow target is available for use without negatively impacting seasonal pool levels or downstream water uses and that all or part of it is subject to withdrawal.

Historical daily outflow data for the lakes were used to determine the quantity of water that potentially could be withdrawn and the resulting quantity of water that would flow downstream (referred to as "flow-by") on a daily basis as a function of all combinations of three hypothetical target minimum flow-by amounts $(1,2$, and 3 times current minimum in-stream flow targets) and three pumping capacities (1, 2, and 3 million gallons per day). Using both U.S. Geological Survey streamgage data and lake-outflow data provided by the U.S. Army Corps of Engineers resulted in analytical periods ranging from 51 calendar years for the Atwood Lake to 73 calendar years for the Leesville and Tappan Lakes.

The observed outflow time series and the computed time series of daily flow-by amounts and potential withdrawals were analyzed to compute and report order statistics (95th, 75th, 50th, 25th, 10th, and 5th percentiles) and means for the analytical period, in aggregate, and broken down by calendar month. In addition, surplus-water mass curve data were tabulated for each of the lakes.

Monthly order statistics of computed withdrawals indicated that, for the three pumping capacities considered, increasing the target minimum flow-by amount tended to reduce the amount of water that can be withdrawn.
The reduction was greatest in the lower percentiles of withdrawal; however, increasing the flow-by amount had no impact on potential withdrawals during high flow. In addition, for a given target minimum flow-by amount, increasing the pumping rate increased the total amount of water that could be withdrawn; however, that increase was less than a direct multiple of the increase in pumping rate for most flow statistics. Potential monthly withdrawals were observed to be more variable and more limited in some calendar months than others.

Monthly order statistics and means of computed daily mean flow-by amounts indicated that flow-by amounts generally tended to be lowest during June-October and February. Increasing the target minimum flow-by amount for a given pumping rate resulted in some small increases in the magnitudes of the mean and 50th percentile and lower order statistics of computed mean flow-by, but had no effect on the magnitudes of the higher percentile statistics. Increasing the pumping rate for a given target minimum flow-by amount resulted in decreases in magnitudes of higher-percentile flow-by statistics by an amount equal to the flow equivalent of the increase in pumping rate; however, some lower percentile statistics remained unchanged.

\section{Introduction}

The Muskingum Watershed Conservancy District (MWCD) - a political subdivision of the State of Ohio-was created in 1933 under the Conservancy Act (Ohio Revised Code, Chapter 6101) (LAWriter Ohio Laws and Rules, 2000). In addition to flood reduction and protection, other approved purposes of the MWCD include conserving and developing water supplies for domestic, industrial, and public use; treating wastewater; and providing recreational opportunities. In support of the MWCD's role in developing water supplies, a study was conducted by the U.S. Geological Survey (USGS), in cooperation with the MWCD, to assess potential water availability from the Atwood, Leesville, and Tappan Lakes, located within the Muskingum River Watershed, Ohio (fig. 1). These lakes, which have been operational since fall 1936, are operated by the U.S. Army Corps of Engineers (USACE) in partnership with the MWCD. 


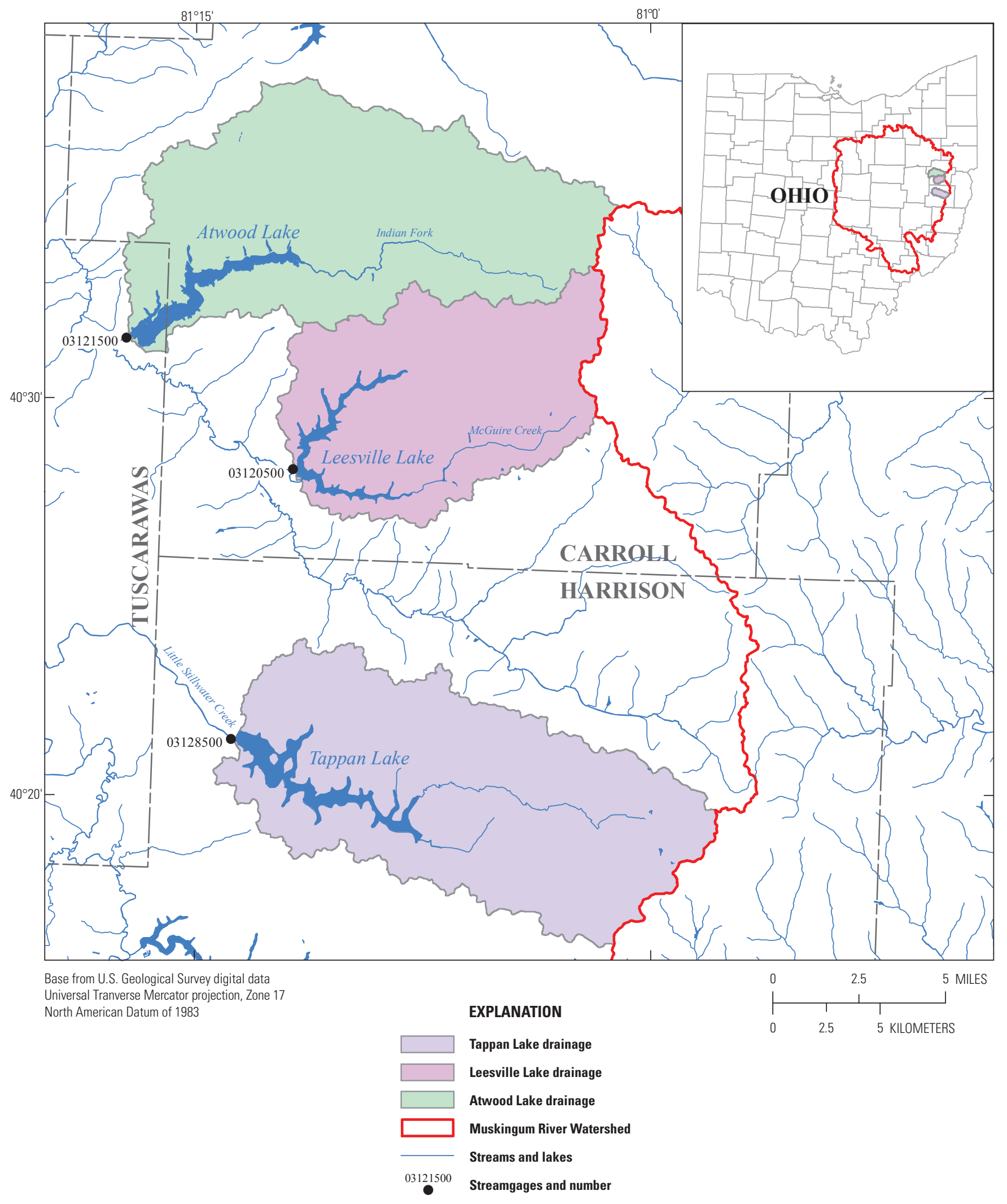

Figure 1. Locations of lakes and streamgages in the Muskingum River Watershed, Ohio. 
The MWCD stipulated that the water-availability assessment be based on the criterion that water withdrawals should not appreciably affect maintenance of recreation-season pool levels in current use. To facilitate and simplify the water-availability analyses, it was assumed that historical lake operations were successful in maintaining seasonal pool levels, and that any discharges from the lakes constituted either water that was discharged to prevent exceeding seasonal pool levels or discharges intended to meet minimum in-stream flow targets downstream from the lakes. It is assumed that volumes of water discharged in excess of minimum in-stream flow targets (hereafter referred to as "surplus water") are, by definition, available for use without negatively impacting seasonal pool levels or downstream water uses. The residual lake outflow (that is, the outflow minus withdrawals, if any) will be referred to as the "flow-by" because that water flows by (or through) the lake and is available for downstream uses.

\section{Descriptions of the Lakes}

The lakes addressed in this report include Atwood, Leesville, and Tappan. The dams that form these lakes were all completed in 1936. While the primary purpose of the lakes is flood control, they also were designed to provide storage for water conservation and recreation and to promote fish and wildlife enhancement.

Atwood Lake, which has a drainage area of about 70 square miles $\left(\mathrm{mi}^{2}\right)$, is located in Tuscarawas and Carroll Counties, Ohio, on the Indian Fork of Conotton Creek (fig. 1). The Atwood Dam is a 65 feet (ft) high rolled-earth fill with impervious core (U.S. Army Corps of Engineers, 2013a). The outlet works consist of an approach channel, intake structure, tri-channeled conduit, stilling basin, and outlet channel (U.S. Army Corps of Engineers, 2005).

Leesville Lake, which has a drainage area of about $48.3 \mathrm{mi}^{2}$, is located in southwest Carroll County, Ohio, on McGuire Creek (a tributary of Conotton Creek) (fig. 1). The Leesville Dam is a $74 \mathrm{ft}$ high rolled-earth fill with impervious core (U.S. Army Corps of Engineers, 2013b). The outlet works consist of an approach channel, intake structure, horseshoeshaped tunnel, open-cut conduit section, stilling basin, and outlet channel (U.S. Army Corps of Engineers, 2005).

Tappan Lake, which has a drainage area of about $71.1 \mathrm{mi}^{2}$, is located in northwest Harrison County, Ohio, on Little Stillwater Creek (fig. 1). The Tappan Dam is a $52 \mathrm{ft} \mathrm{high}$ rolled-earth fill with impervious core (U.S. Army Corps of
Engineers, 2013c). The outlet works consist of an approach channel, intake structure, horseshoe-shaped tunnel, stilling basin, and outlet channel (U.S. Army Corps of Engineers, 2005).

At each of the lakes previously discussed, normal flow (that is, when inflows to the lakes result in pool levels that are lower than emergency spillways present at each lake) is controlled by three $3.5 \mathrm{ft}$ by $7 \mathrm{ft}$ sluice gates. In addition, two ungated $1.5 \mathrm{ft}$ diameter siphons are used at each lake to help maintain the minimum pool elevation. The USACE has set minimum in-stream flow targets, immediately downstream from the lakes, of 1.5 cubic feet per second $\left(\mathrm{ft}^{3} / \mathrm{s}\right)$ for Atwood and Leesville and $2.0 \mathrm{ft}^{3} / \mathrm{s}$ for Tappan. It is worth noting that during very dry periods, it is possible to release less than the minimum in-stream flow target (if the lake level falls below the exposed circular intake to the siphons). Also, because of gate leakage, it is possible that flows as low as the minimum in-stream flow targets do not occur (Timothy Curran, U.S. Army Corps of Engineers, Huntington District, written commun., 2012).

\section{Purpose and Scope}

The purpose of this report is to describe analytical methods and present results of a study to assess potential water availability from the Atwood, Leesville, and Tappan Lakes in the Muskingum River Watershed, Ohio. The analysis involved determining the amounts of water that potentially could be withdrawn and the resulting amounts of water that would flow downstream on a daily basis as a function of all combinations of three hypothetical target minimum flow-by amounts $(1,2$, and 3 times current minimum in-stream flow targets) and three pumping capacities $(1,2$, and 3 million gallons per day $(\mathrm{Mgal} / \mathrm{d}))$. The analysis was based on an examination of the best available historical daily outflow data for the lakes.

\section{Flow Data Used in the Analyses}

Lake-outflow data used for this report came from either daily mean streamflows published by the USGS for streamgages located short distances downstream from the outlet works of the lakes (table 1 and fig. 1) or from daily mean outflow data provided by the USACE. The streamflow data published by the USGS were determined based on relations developed between water-level data and physical measurements of streamflow. The USACE stated that they typically

Table 1. U.S. Geological Survey streamgages and periods of gage record used in the water-availability analyses for the Muskingum River Watershed, Ohio.

\begin{tabular}{clc}
\hline Station number & \multicolumn{1}{c}{ Station name } & Period of streamgage record used \\
\hline 03121500 & Indian Fork below Atwood Dam near New Cumberland, Ohio & $01 / 01 / 1961-09 / 30 / 1975$ \\
03120500 & McGuire Creek near Leesville, Ohio & $01 / 01 / 1939-09 / 30 / 1991$ \\
03128500 & Little Stillwater Creek below Tappan Dam at Tappan, Ohio & $01 / 01 / 1939-09 / 30 / 1991$ \\
\hline
\end{tabular}


used gate and siphon ratings to compute the outflows for the lakes and indicated that the accuracy of their reported flows may be poor during some low-flow periods (for example, due to unaccounted for gate leakages) (Timothy Curran, U.S. Army Corps of Engineers, Huntington District, written commun., June, 2012).

Pearson's correlation coefficient ( $\mathrm{r}$ ), which measures the strength of the linear relationship between two variables, was computed for each lake for the relation between sameday USGS-published streamflows and USACE-computed outflows. Pearson's $r$ can range from -1 to 1 where an $r$ of \pm 1 indicates a perfect linear relationship between variables and an $\mathrm{r}$ of 0 indicates no linear relationship between variables. When considering all concurrent flow data, the $\mathrm{r}$ values ranged from a low of 0.95 to a high of 0.96 for the three lake outflows. Correlation coefficients computed based on only those paired flow values where the USACE outflow was reported to be less than or equal to $10 \mathrm{ft}^{3} / \mathrm{s}$, were considerably smaller ( $\mathrm{r}$ ranging from 0.19 to 0.60 ), indicating poorer correlation than for the full data set. For all three lakes, the largest differences between the USGS-published streamflows and the USACE-computed outflows for flows less than or equal to $10 \mathrm{ft}^{3} / \mathrm{s}$ predominately were associated with times when the USGS-published streamflows were larger than the USACE-computed outflows.

Because of the stated uncertainty surrounding the lowflow data supplied by the USACE, the USGS streamgage data were used whenever available; USACE data were used at other times. The resulting daily-mean-outflow time series will henceforth be referred to as the "observed" outflows.

The three USGS streamgages whose data were used in this report, along with the periods of record used, are shown in table 1. The USACE provided lake-outflow data for the period 01/01/1962 to12/31/2011 for the Atwood, Leesville, and Tappan Lakes. Using both streamgage and outflow data provided by the USACE resulted in analytical periods ranging from 51 calendar years (1961-2011) for Atwood Lake to 73 calendar years (1939-2011) for the Leesville and Tappan Lakes.

\section{Methods of Analysis}

To assess potential future water availability, observed outflow data from the Atwood, Leesville, and Tappan Lakes were used to determine the amounts of water that potentially could be withdrawn and the resulting residual amounts of water that would flow downstream (referred to as "flow-by") on a daily basis as a function of all combinations of three hypothetical target minimum flow-by amounts and three pumping capacities. It is worth noting that the "target minimum flow-by amounts" represent targets (not regulatory mandates) for minimum daily mean flows immediately downstream from the lakes; however, there may be times when those targets cannot be met. The occasional inability to fulfill those targets in this analysis occurs because the flow-by comes from observed lake outflows, which at times was already less than the target.
This might occur, for example, during extended dry periods when lake outflows are completely controlled by the siphons. Irrespective of the actual outflows from the lakes, in no case does the analytical method used for this report yield flow-by amounts less than the observed lake outflows.

The target minimum flow-by amounts used in this analysis were 1,2, and 3 times the current minimum instream flow targets for the lakes $\left(1.5 \mathrm{ft}^{3} / \mathrm{s}\right.$ for the Atwood and Leesville Lakes and $2.0 \mathrm{ft}^{3} / \mathrm{s}$ for Tappan Lake) as specified by the USACE. The pumping rates used in this analysis were 1,2 , and $3 \mathrm{Mgal} / \mathrm{d}$. Pumping rates and multipliers for target minimum flow-by amounts used in this analysis were specified by the MWCD.

As illustrated in figure 2, for each day in the lake outflow time series, the outflow amount was compared to the target minimum flow-by amount. If the outflow amount did not exceed the target minimum flow-by amount, then there was no surplus water available for withdrawal and the total outflow was designated as flow-by. If instead the outflow amount exceeded the target minimum flow-by amount, then the amount of outflow in excess of that target minimum flow-by amount was said to be surplus water.

The amount of surplus water was compared to the amount of water that could be pumped (withdrawn) in 1 day at the specified pumping rate. If the amount of surplus water exceeds that which could be pumped, then the withdrawal was set equal to the product of time and the pumping rate. For example, if the pumping rate was $1 \mathrm{Mgal} / \mathrm{d}$, then the amount of water that could be pumped over a 24 hour period equals 1 million gallons (Mgal). If instead the amount of surplus water did not exceed that which could be pumped in 1 day, then the withdrawal was set equal to the amount of surplus water (the assumption being that the pump would be operated only for the portion of the day required to pump the surplus amount). The resulting flow-by amount (that is the water that flows downstream) is equal to the outflow minus withdrawals (if any). This approach ensures that the resulting flow-by amount equals or exceeds the target minimum flow-by amount whenever the outflow exceeds the target minimum flow by.

The observed outflow time series and the time series of daily flow-by amounts and potential withdrawals (computed as previously described) were analyzed to compute order statistics and means. The order statistics computed include the 95th, 75th, 50th, 25th, 10th, and 5th percentiles. In general, the Pth percentile refers to the value in the series that is greater than or equal to $\mathrm{P}$ percent of values in the series. Conversely, the Pth percentile value is less than or equal to 100-P percent of the values in the series. For example, the 5 th percentile value is greater than or equal to 5 percent of the values in the series and less than or equal to 95 percent (100-5 percent) of the values.

Order statistics and means were computed for daily mean observed outflows and computed flow-by amounts, as well as for monthly and annual total withdrawals. The ultimate objective of computing order statistics is to provide information on the frequency with which outflows, flow-by amounts, and 


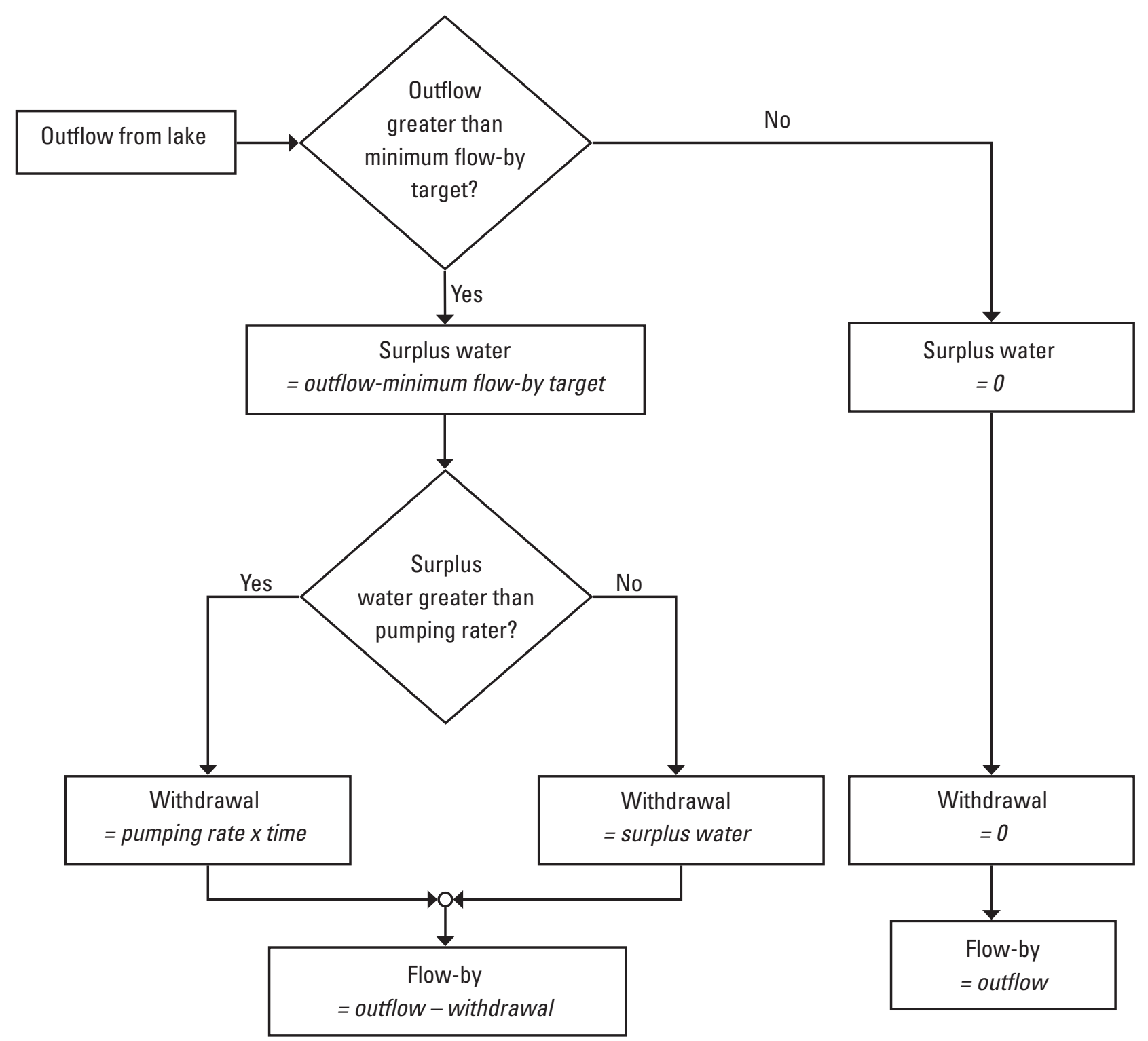

Figure 2. Flowchart outlining the logic by which withdrawal and flow-by amounts were determined.

withdrawals with various magnitudes were exceeded (or not exceeded). Order statistics were computed with the Statistical Analysis System (SAS) (SAS Institute, Inc., 2011) using the SAS type 5 estimator (which calculates percentiles based on the empirical distribution function with averaging when the percentile boundary lies between two observations). For some tables presented in this report, statistics are reported for the aggregate analytical period; for other tables, order statistics were computed based on data further subdivided by calendar month. The aggregate analytical-period order statistics provide information on exceedance/nonexceedance without consideration for seasonality, whereas the monthly order statistics provide more information about seasonal variation in the flows and potential withdrawals.
Cumulative surplus-water volumes were tabulated as a function of time for the Atwood, Leesville, and Tappan Lakes based on target minimum outflows equal to 1,2, and 3 times current target minimum outflows. When cumulative volumes are plotted as a function of time, they are called mass curves. Both tabular and graphical versions of surplus-water mass curves can be used to assess hypothetical water-demand rates to determine whether the demand could have been met at all times or, if not, to determine the maximum amount and duration of demand excess. 


\section{Results and Discussion}

Order statistics and means of calendar-year and monthly total withdrawals are shown in tables $2-5$ for the various combinations of pumping rates and target minimum flow-by amounts. The data presented in table 2 show some general trends in withdrawal statistics for the Atwood, Leesville, and Tappan Lakes. Specifically, for any of the given pumping rates, increasing the target minimum flow-by amount tends to reduce the amount of water that can be withdrawn. The reduction is greatest in the lower percentiles of withdrawal because increasing the flow-by amount has a large impact on water available for withdrawal during low-flow periods; however, increasing the flow-by amount has no impact on potential withdrawals during high-flow periods because the amount of surplus water (from which withdrawals are made) already far exceeds pumping rates.

For a given target minimum flow-by amount, increasing the pumping rate typically increases the total amount of water that can be withdrawn; however, that increase is less than a direct multiple of the increase in pumping rate for most statistics. This is because sufficient surplus water is available on some days to meet the demand associated with smaller pumping rates, but it may not be sufficient to meet the demand associated with larger pumping rates. When the amount of surplus water is not sufficient to meet the full demand associated with an increased pumping rate, the amount of additional withdrawal (beyond that which is associated with the lower pumping rate) will range from zero to some fraction of the difference in pump capacities.

Withdrawal data shown in tables 3-5 illustrate that potential monthly withdrawals are more variable and more limited in some calendar months than others. For example, withdrawal results for Atwood Lake (table 3) indicate that, irrespective of which target minimum flow-by amount is used, $1 \mathrm{Mgal}$ of water could have been withdrawn daily at a pumping rate of $1 \mathrm{Mgal} / \mathrm{d}$ on at least 90 percent of the April months; however, that same amount of withdrawal was possible on a smaller percentage of the September months. For example, with a pumping rate of $1 \mathrm{Mgal} / \mathrm{d}$ and a target minimum flow-by amount of $4.5 \mathrm{ft}^{3} / \mathrm{s}$, a daily withdrawal of $1 \mathrm{Mgal}$ was not possible for Atwood Lake on at least 25 percent of September months. At that same pumping rate and target minimum flow-by amount, no water could be withdrawn from Atwood Lake on at least 5 percent of the September months.

Aggregate analytical-period order statistics and monthly order statistics of observed daily mean outflows are reported in tables 6 and 7, respectively. Data from these tables provide a base against which to compare flow-by statistics from the analyses employing the various combinations of pumping and target minimum flow-by amounts. An examination of the data presented in table 7 indicates that the daily mean observed outflows for the Atwood, Leesville, and Tappan Lakes tend to be lowest during June-October, although February also stands out as having relatively low mean outflows. The relatively low mean outflows for February likely reflect the fact that February typically is one of the driest months in Ohio (Ohio Department of Natural Resources, 2011).

Aggregate analytical-period order statistics and means of computed daily mean flow-by amounts are shown in table 8 for the Atwood, Leesville, and Tappan Lakes for the various combinations of pumping rates and target minimum flow-by amounts. The data show that increases in the target minimum flow-by amounts for a given pumping rate resulted in some small increases in the magnitudes of the means and 25th percentile and smaller order statistics, but had no effect on the magnitudes of the higher percentile statistics. Also, increases in the pumping rate for a given target minimum flow-by amount resulted in decreases in magnitudes of higher-percentile flow statistics by an amount equal to the flow equivalent of the increase in pumping rate; however, some lower-percentile flow statistics remained unchanged because they represent days during which there was no surplus water (and so withdrawals could not be increased on those days in spite of increases in pumping rate).

Monthly order statistics and means of computed daily mean flow-by amounts are shown in tables 9-11 for the Atwood, Leesville, and Tappan Lakes, respectively, for the various combinations of pumping rates and target minimum flow-by amounts. Similar to the observed outflows, computed mean flow-by amounts generally tended to be lowest during June-October and mean flow-by amounts for February also tended to be relatively low. The data in tables 9-11 show that increases in the target minimum flow-by amounts for a given pumping rate resulted in some small increases in the magnitudes of the mean and 50th percentile and lower order statistics, but had no effect on the magnitudes of the higher percentile statistics. As was observed with the aggregate analytical-period order statistics, increases in the pumping rate for a given target minimum flow-by amount resulted in decreases in magnitudes of higher-percentile flow statistics by an amount equal to the flow equivalent of the increase in pumping rate; however, some lower percentile statistics remained unchanged. 
Table 2. Statistics of calendar-year potential withdrawals for the Atwood, Leesville, and Tappan Lakes in the Muskingum River Watershed, Ohio.

[Mgal/d, million gallons per day; minimum in-stream flow targets equal 1.5 cubic feet per second $\left(\mathrm{ft}^{3} / \mathrm{s}\right)$ for Atwood and Leesville Lakes and $2.0 \mathrm{ft}^{3} / \mathrm{s}$ for Tappan Lake]

\begin{tabular}{|c|c|c|c|c|c|c|c|c|c|}
\hline \multirow{4}{*}{ Statistic } & \multicolumn{9}{|c|}{$\begin{array}{l}\text { Calendar-year potential withdrawals, in millions of gallons, for indicated lakes, pumping rates, } \\
\text { and minimum in-stream flow-target multiples }\end{array}$} \\
\hline & \multicolumn{9}{|c|}{ Pumping rate, in Mgal/d } \\
\hline & \multicolumn{9}{|c|}{ Minimum in-stream flow-target multiple } \\
\hline & 1 & 2 & 3 & 1 & 2 & 3 & 1 & 2 & 3 \\
\hline 75th percentile & 365 & 364 & 364 & 729 & 728 & 724 & 1092 & 1089 & 1085 \\
\hline mean & 351 & 338 & 332 & 689 & 670 & 658 & 1020 & 995 & 978 \\
\hline 50th percentile & 361 & 358 & 355 & 719 & 714 & 708 & 1075 & 1063 & 1059 \\
\hline 25th percentile & 341 & 319 & 305 & 652 & 627 & 609 & 961 & 916 & 910 \\
\hline 95th percentile & 365 & 362 & 354 & 726 & 716 & 705 & 1080 & 1066 & 1044 \\
\hline 75th percentile & 354 & 335 & 321 & 685 & 651 & 633 & 999 & 957 & 925 \\
\hline mean & 321 & 293 & 276 & 613 & 568 & 535 & 887 & 827 & 782 \\
\hline 50th percentile & 331 & 301 & 276 & 632 & 577 & 522 & 905 & 828 & 762 \\
\hline 25 th percentile & 293 & 256 & 241 & 548 & 498 & 461 & 793 & 723 & 666 \\
\hline 10th percentile & 276 & 227 & 204 & 505 & 421 & 390 & 708 & 616 & 569 \\
\hline 5th percentile & 240 & 209 & 186 & 448 & 394 & 365 & 646 & 573 & 534 \\
\hline \multicolumn{10}{|c|}{ Tappan Lake } \\
\hline 95th percentile & 364 & 364 & 361 & 728 & 723 & 717 & 1088 & 1082 & 1075 \\
\hline 5th percentile & 244 & 203 & 179 & 452 & 388 & 351 & 650 & 558 & 513 \\
\hline
\end{tabular}


Table 3. Statistics of Atwood Lake, Ohio, total monthly potential withdrawals for indicated pumping rates and target minimum flow-by amounts.

$\left[\mathrm{ft}^{3} / \mathrm{s}\right.$, cubic foot per second; Mgal/d, million gallons per day]

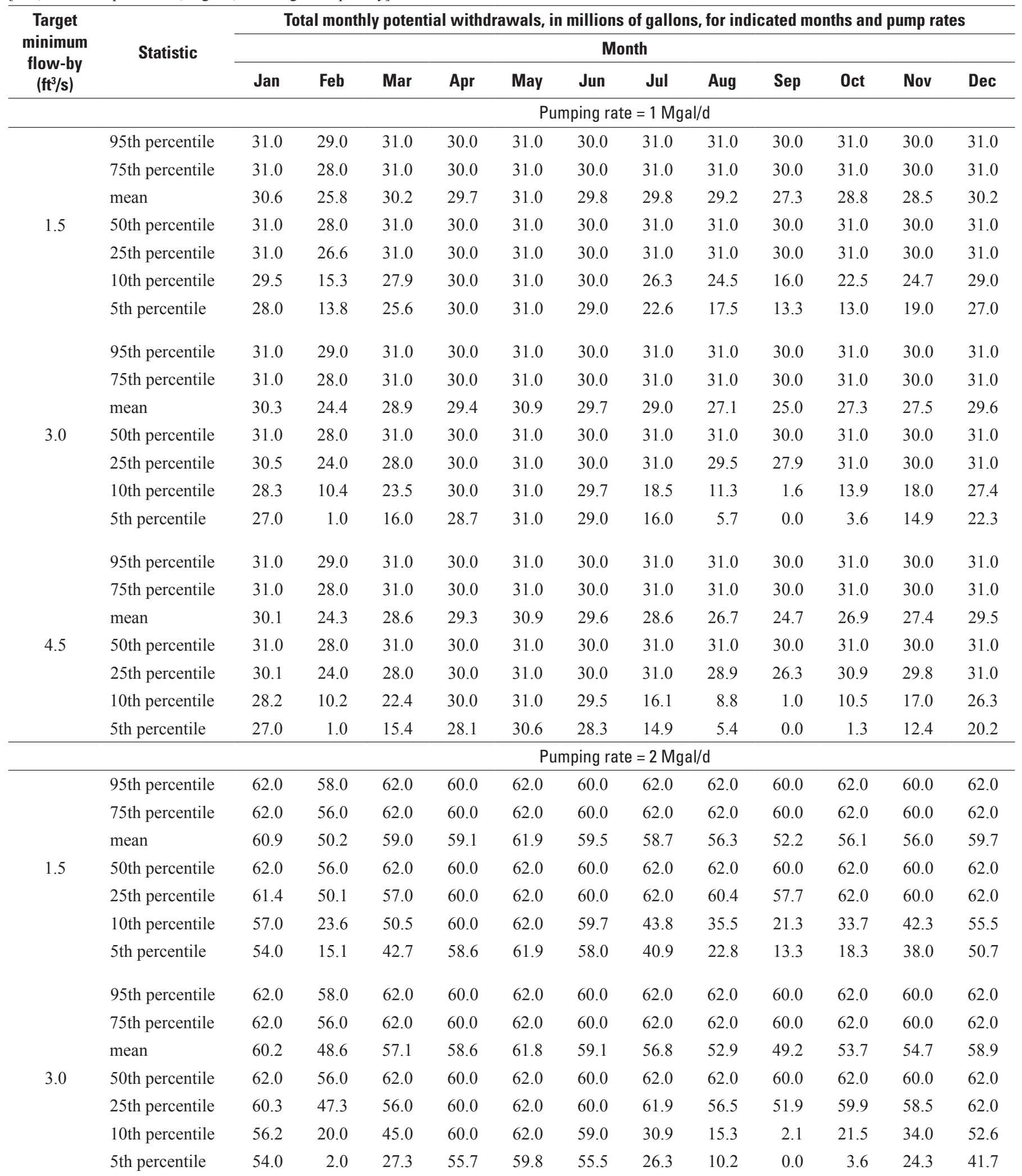


Table 3. Statistics of Atwood Lake, Ohio, total monthly potential withdrawals for indicated pumping rates and target minimum flow-by amounts.-Continued

[ft $/ \mathrm{s}$, cubic foot per second; Mgal/d, million gallons per day]

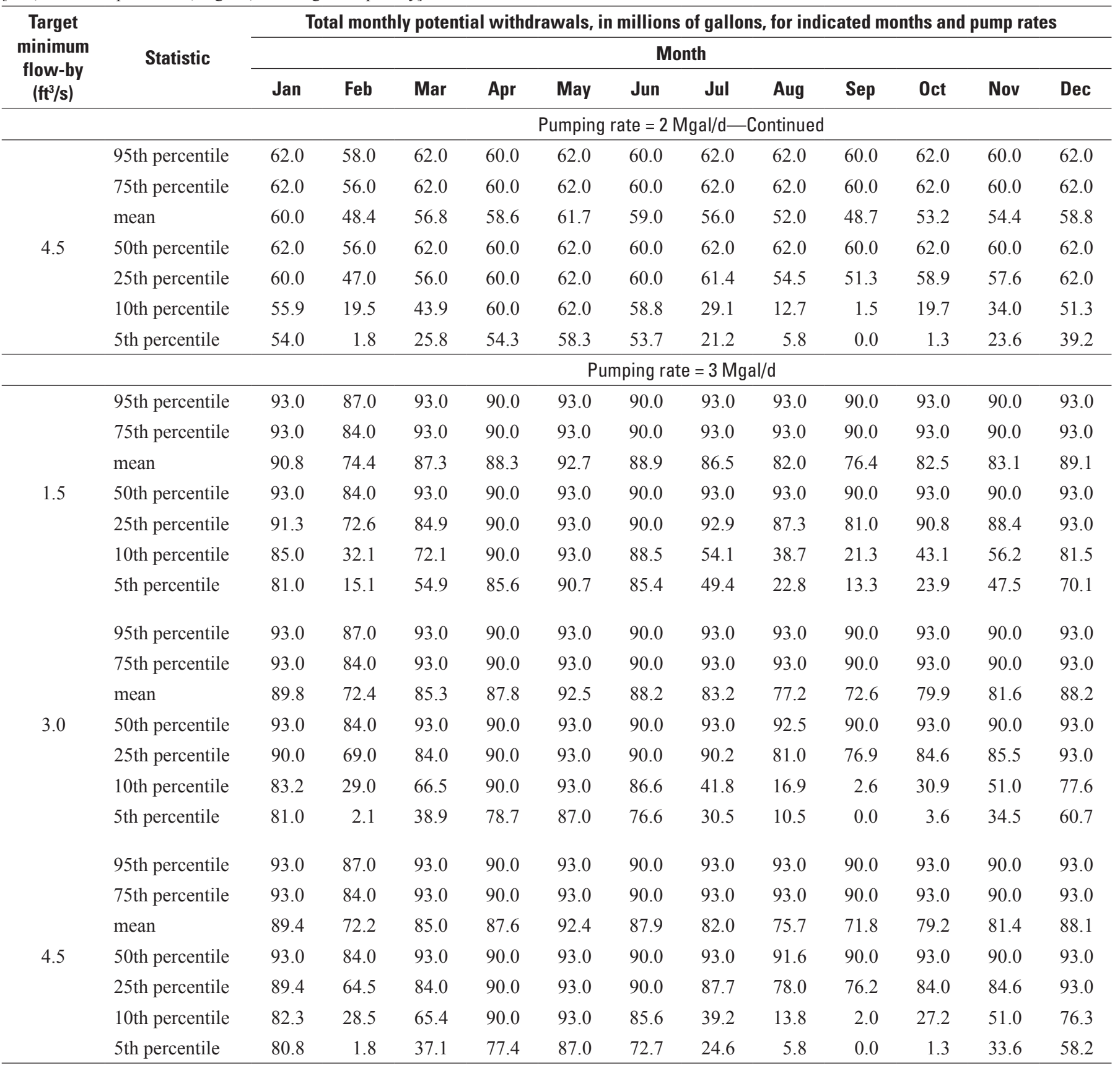


Table 4. Statistics of Leesville Lake, Ohio, total monthly potential withdrawals for indicated pumping rates and target minimum flow-by amounts.

[ft $3 / \mathrm{s}$, cubic foot per second; Mgal/d, million gallons per day]

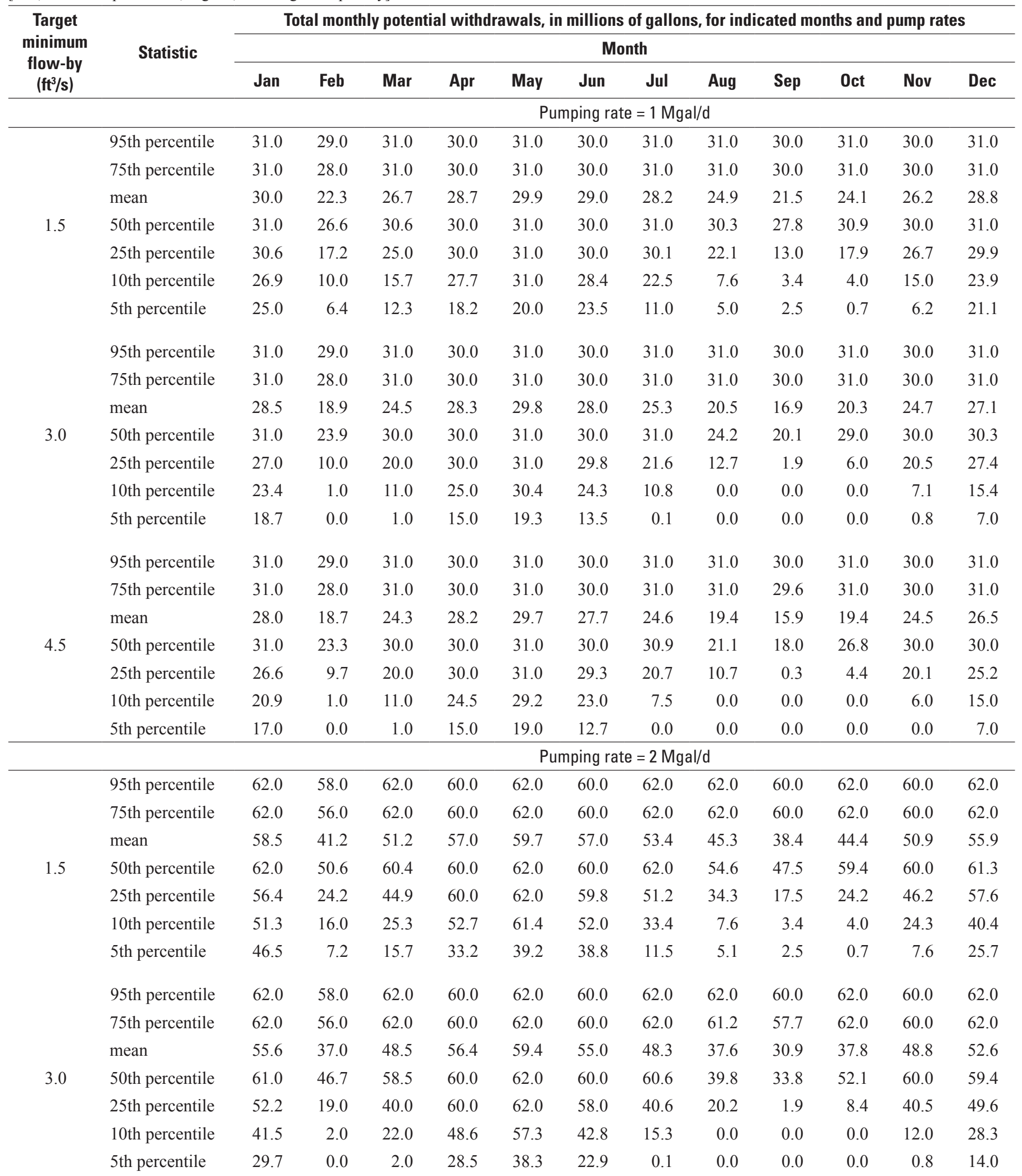


Table 4. Statistics of Leesville Lake, Ohio, total monthly potential withdrawals for indicated pumping rates and target minimum flow-by amounts.-Continued

[ $\mathrm{ft}^{3} / \mathrm{s}$, cubic foot per second; Mgal/d, million gallons per day]

\begin{tabular}{|c|c|c|c|c|c|c|c|c|c|c|c|c|c|}
\hline \multirow{3}{*}{$\begin{array}{c}\text { Target } \\
\text { minimum } \\
\text { flow-by } \\
\left(\mathrm{ft}^{3} / \mathrm{s}\right)\end{array}$} & \multirow{3}{*}{ Statistic } & \multicolumn{12}{|c|}{ Total monthly potential withdrawals, in millions of gallons, for indicated months and pump rates } \\
\hline & & \multicolumn{12}{|c|}{ Month } \\
\hline & & Jan & Feb & Mar & Apr & May & Jun & Jul & Aug & Sep & Oct & Nov & Dec \\
\hline \multirow{6}{*}{4.5} & 95th percentile & 62.0 & 57.9 & 62.0 & 60.0 & 62.0 & 60.0 & 62.0 & 62.0 & 60.0 & 62.0 & 60.0 & 62.0 \\
\hline & 75th percentile & 62.0 & 56.0 & 62.0 & 60.0 & 62.0 & 60.0 & 62.0 & 59.8 & 56.4 & 62.0 & 60.0 & 62.0 \\
\hline & 50th percentile & 60.6 & 42.8 & 58.0 & 60.0 & 62.0 & 60.0 & 59.4 & 36.5 & 27.9 & 49.6 & 59.6 & 58.7 \\
\hline & 25th percentile & 50.0 & 18.7 & 39.7 & 60.0 & 62.0 & 57.7 & 37.2 & 16.8 & 0.3 & 4.4 & 40.1 & 47.3 \\
\hline & 10th percentile & 40.9 & 2.0 & 22.0 & 47.5 & 55.7 & 37.8 & 10.3 & 0.0 & 0.0 & 0.0 & 12.0 & 27.0 \\
\hline & 5th percentile & 23.5 & 0.0 & 1.9 & 28.2 & 37.8 & 19.4 & 0.0 & 0.0 & 0.0 & 0.0 & 0.0 & 10.1 \\
\hline \multirow{5}{*}{1.5} & mean & 85.6 & 59.2 & 75.1 & 85.1 & 89.3 & 83.9 & 76.3 & 62.3 & 52.3 & 61.8 & 75.0 & 81.4 \\
\hline & 50th percentile & 91.9 & 74.1 & 89.0 & 90.0 & 93.0 & 90.0 & 91.5 & 68.3 & 59.2 & 80.8 & 90.0 & 90.1 \\
\hline & 25th percentile & 81.2 & 29.0 & 64.8 & 90.0 & 93.0 & 87.7 & 64.7 & 39.6 & 17.5 & 29.4 & 64.9 & 79.4 \\
\hline & 10th percentile & 69.3 & 16.2 & 36.3 & 76.3 & 88.1 & 71.8 & 37.4 & 7.6 & 3.4 & 5.0 & 30.5 & 53.7 \\
\hline & 5 th percentile & 59.5 & 7.2 & 15.7 & 46.4 & 58.2 & 43.4 & 11.5 & 5.1 & 2.5 & 0.7 & 7.6 & 28.7 \\
\hline \multirow[b]{4}{*}{3.0} & 95th percentile & 93.0 & 84.0 & 93.0 & 90.0 & 93.0 & 90.0 & 93.0 & 93.0 & 90.0 & 93.0 & 90.0 & 93.0 \\
\hline & 75th percentile & 93.0 & 84.0 & 93.0 & 90.0 & 93.0 & 90.0 & 93.0 & 86.2 & 81.6 & 91.5 & 90.0 & 93.0 \\
\hline & mean & 81.8 & 54.2 & 71.6 & 84.3 & 88.8 & 80.8 & 69.0 & 52.1 & 42.8 & 52.8 & 71.9 & 77.2 \\
\hline & 50th percentile & 89.3 & 63.9 & 87.0 & 90.0 & 93.0 & 90.0 & 85.4 & 51.4 & 40.7 & 70.1 & 88.4 & 88.4 \\
\hline \multirow{5}{*}{4.5} & mean & 80.8 & 53.4 & 71.0 & 84.1 & 88.6 & 79.6 & 66.8 & 49.4 & 40.5 & 50.3 & 71.0 & 76.0 \\
\hline & 50th percentile & 88.7 & 62.2 & 86.3 & 90.0 & 93.0 & 89.9 & 83.0 & 48.0 & 34.1 & 60.2 & 87.3 & 87.7 \\
\hline & 25 th percentile & 73.6 & 27.7 & 51.5 & 90.0 & 93.0 & 83.9 & 48.7 & 16.8 & 0.3 & 4.4 & 57.9 & 68.3 \\
\hline & 10th percentile & 57.5 & 3.0 & 33.0 & 70.0 & 81.7 & 45.6 & 11.0 & 0.0 & 0.0 & 0.0 & 18.0 & 32.6 \\
\hline & 5 th percentile & 33.5 & 0.0 & 1.9 & 42.2 & 55.8 & 20.2 & 0.0 & 0.0 & 0.0 & 0.0 & 0.0 & 10.1 \\
\hline
\end{tabular}


Table 5. Statistics of Tappan Lake, Ohio, total monthly potential withdrawals for indicated pumping rates and target minimum flow-by amounts.

[ft $3 / \mathrm{s}$, cubic foot per second; Mgal/d, million gallons per day]

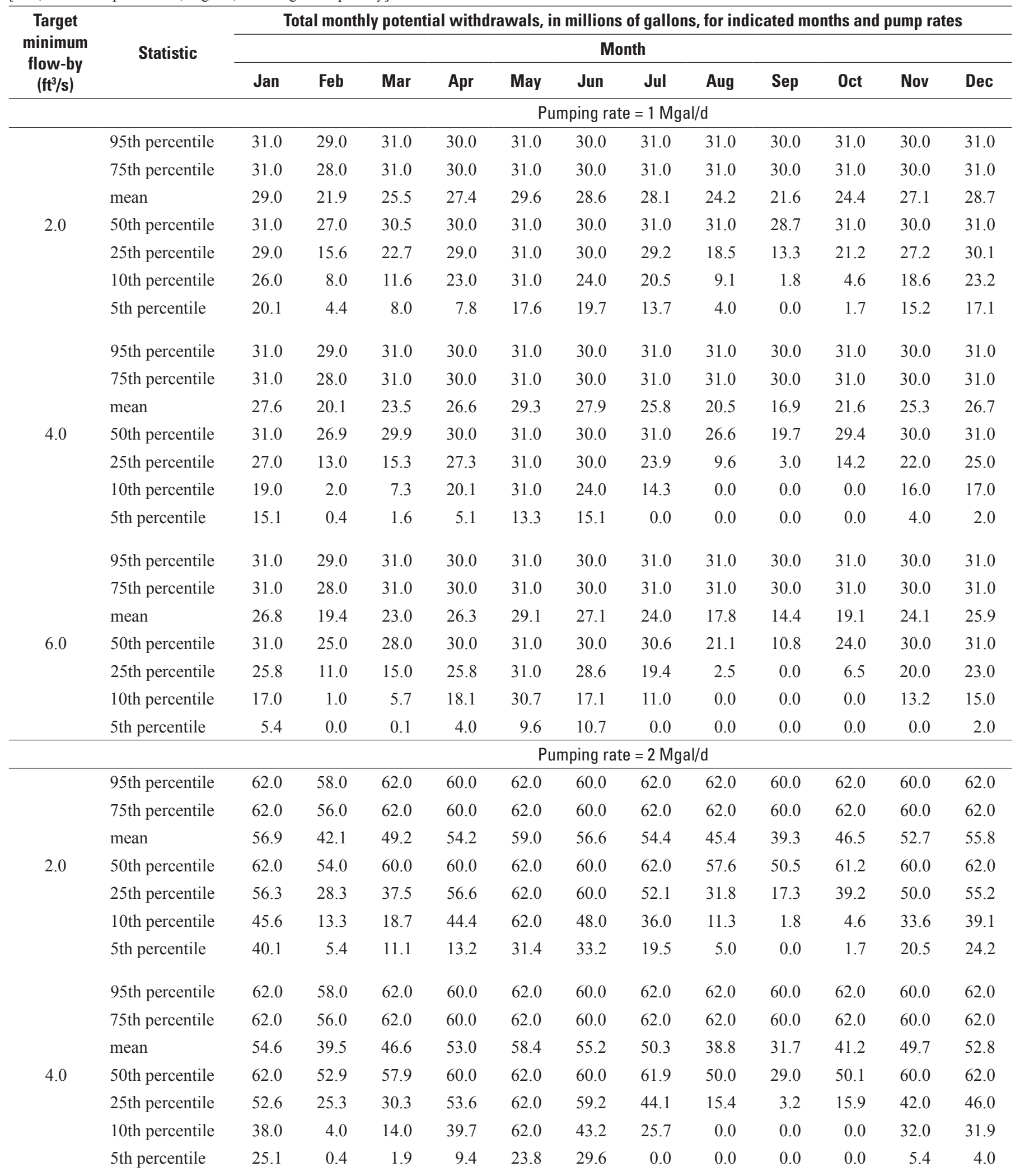


Table 5. Statistics of Tappan Lake, Ohio, total monthly potential withdrawals for indicated pumping rates and target minimum flow-by amounts.-Continued

[ $\mathrm{ft}^{3} / \mathrm{s}$, cubic foot per second; Mgal/d, million gallons per day]

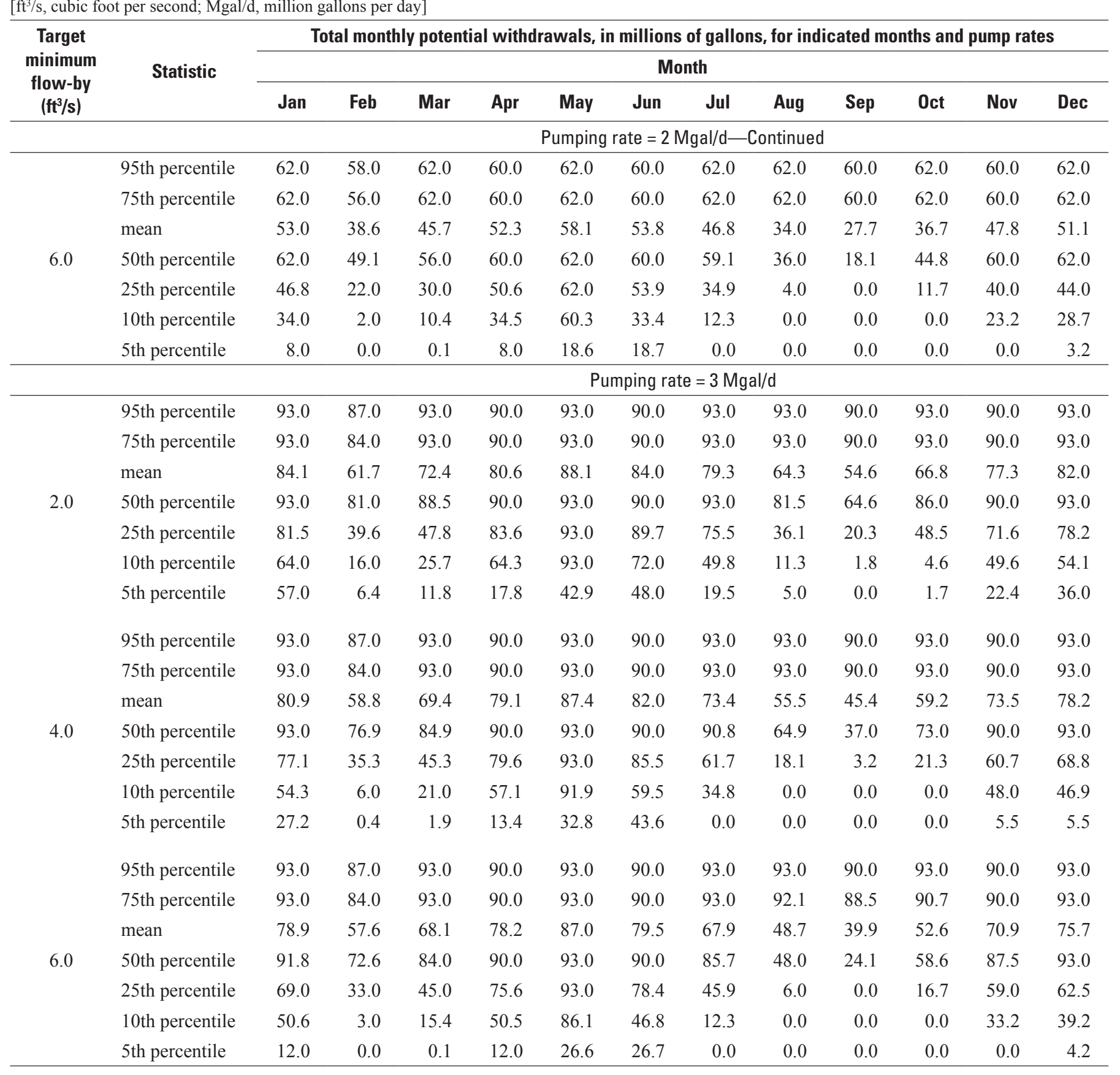


Table 6. Analytical period statistics of observed daily mean outflows from the Atwood, Leesville, and Tappan Lakes in the Muskingum River Watershed, Ohio.

\begin{tabular}{lccc}
\hline \multirow{2}{*}{ Statistic } & \multicolumn{3}{c}{$\begin{array}{c}\text { Observed daily mean outflow amounts for indicated lakes } \\
\text { (in cubic feet per second) }\end{array}$} \\
\cline { 2 - 4 } & Atwood Lake & Leesville Lake & Tappan Lake \\
\hline 95th percentile & 320.0 & 218.7 & 363.0 \\
75th percentile & 105.3 & 88.0 & 105.5 \\
mean & 85.4 & 58.8 & 80.8 \\
50th percentile & 52.9 & 24.4 & 25.6 \\
25th percentile & 13.0 & 5.5 & 7.5 \\
10th percentile & 6.2 & 2.0 & 2.2 \\
5th percentile & 2.6 & 1.6 & 1.7 \\
& & & \\
Minimum in-stream & 1.5 & 1.5 & 2.0 \\
$\quad$ flow target & & & \\
\hline
\end{tabular}

Table 7. Statistics of observed daily mean outflows by month for the Atwood, Leesville, and Tappan Lakes in the Muskingum River Watershed, Ohio.

\begin{tabular}{|c|c|c|c|c|c|c|c|c|c|c|c|c|}
\hline \multirow{3}{*}{ Statistic } & \multicolumn{12}{|c|}{ Observed daily mean reservoir outflows, in cubic feet per second, for indicated month and lake } \\
\hline & \multicolumn{12}{|c|}{ Month } \\
\hline & Jan & Feb & Mar & Apr & May & Jun & Jul & Aug & Sep & Oct & Nov & Dec \\
\hline & \multicolumn{12}{|c|}{ Atwood Lake } \\
\hline 95th percentile & 320.0 & 364.5 & 413.0 & 400.0 & 343.0 & 291.0 & 146.4 & 119.6 & 131.0 & 155.0 & 268.1 & 392.0 \\
\hline 75th percentile & 110.5 & 73.1 & 143.0 & 180.5 & 122.8 & 88.6 & 73.0 & 55.7 & 50.1 & 63.0 & 161.0 & 183.6 \\
\hline mean & 84.1 & 74.2 & 108.5 & 145.9 & 110.0 & 83.8 & 54.2 & 41.5 & 43.4 & 47.4 & 110.6 & 122.2 \\
\hline 50th percentile & 32.0 & 16.0 & 76.0 & 99.9 & 76.0 & 62.0 & 44.9 & 21.2 & 17.7 & 25.0 & 98.0 & 67.7 \\
\hline 25 th percentile & 18.0 & 10.7 & 11.2 & 72.1 & 55.7 & 28.0 & 11.0 & 7.8 & 8.2 & 11.2 & 42.0 & 22.0 \\
\hline 10th percentile & 10.6 & 2.2 & 10.0 & 35.5 & 35.0 & 12.0 & 5.2 & 3.1 & 2.4 & 3.1 & 8.9 & 10.7 \\
\hline \multirow[t]{2}{*}{ 5th percentile } & 6.7 & 1.9 & 3.0 & 11.1 & 17.0 & 8.7 & 2.8 & 2.2 & 1.9 & 2.0 & 2.6 & 10.3 \\
\hline & \multicolumn{12}{|c|}{ Leesville Lake } \\
\hline 95th percentile & 230.0 & 257.0 & 272.0 & 250.0 & 225.0 & 194.0 & 116.9 & 87.4 & 133.0 & 127.0 & 206.4 & 246.1 \\
\hline 75th percentile & 111.4 & 108.4 & 138.0 & 139.8 & 105.7 & 65.2 & 32.0 & 15.7 & 12.0 & 22.0 & 124.0 & 136.0 \\
\hline mean & 70.6 & 69.0 & 91.8 & 101.2 & 75.5 & 51.3 & 29.2 & 18.8 & 20.7 & 25.6 & 73.3 & 80.3 \\
\hline 50th percentile & 43.0 & 24.0 & 67.0 & 82.7 & 52.0 & 22.0 & 11.0 & 6.2 & 4.8 & 6.5 & 59.0 & 47.0 \\
\hline 25 th percentile & 13.0 & 2.3 & 6.5 & 45.0 & 22.0 & 9.8 & 5.1 & 2.6 & 2.0 & 2.4 & 7.8 & 11.0 \\
\hline 10th percentile & 4.4 & 1.8 & 1.9 & 16.6 & 11.0 & 5.2 & 2.3 & 1.7 & 1.5 & 1.5 & 1.8 & 2.8 \\
\hline \multirow[t]{2}{*}{ 5th percentile } & 2.8 & 1.6 & 1.7 & 2.6 & 7.3 & 3.1 & 1.8 & 1.5 & 1.2 & 1.2 & 1.2 & 1.9 \\
\hline & \multicolumn{12}{|c|}{ Tappan Lake } \\
\hline 95th percentile & 428.5 & 432.0 & 426.0 & 418.0 & 387.0 & 284.0 & 154.0 & 87.0 & 82.0 & 195.0 & 374.0 & 425.6 \\
\hline 75th percentile & 155.0 & 141.0 & 162.0 & 187.0 & 124.0 & 60.0 & 34.0 & 18.2 & 17.0 & 25.0 & 213.1 & 192.0 \\
\hline mean & 103.7 & 94.9 & 110.6 & 127.7 & 102.9 & 64.5 & 35.9 & 25.3 & 23.4 & 35.9 & 126.1 & 120.7 \\
\hline 50th percentile & 50.0 & 17.0 & 51.0 & 68.0 & 56.5 & 30.2 & 16.0 & 8.9 & 6.1 & 10.4 & 98.0 & 60.3 \\
\hline 25 th percentile & 14.0 & 2.8 & 5.6 & 33.0 & 30.0 & 16.0 & 7.8 & 3.0 & 2.4 & 3.4 & 12.1 & 12.0 \\
\hline 10th percentile & 4.5 & 2.0 & 2.1 & 3.3 & 16.0 & 7.3 & 2.9 & 1.7 & 1.7 & 2.0 & 2.8 & 3.5 \\
\hline 5th percentile & 2.2 & 1.5 & 1.4 & 1.7 & 3.8 & 3.1 & 1.8 & 1.0 & 1.2 & 1.6 & 2.1 & 2.3 \\
\hline
\end{tabular}


Table 8. Statistics of daily mean flow-by amounts for indicated pumping rates and target minimum flow-by multiples for the Atwood, Leesville, and Tappan Lakes in the Muskingum River.

$\left[\mathrm{ft}^{3} / \mathrm{s}\right.$, cubic foot per second; Mgal/d, million gallons per day; target minimum flow-bys equal $1.5 \mathrm{ft}^{3} / \mathrm{s}$ for Atwood and Leesville Lakes and $2.0 \mathrm{ft}^{3} / \mathrm{s}$ for Tappan Lake]

\begin{tabular}{|c|c|c|c|c|c|c|c|c|c|}
\hline \multirow{4}{*}{ Statistic } & \multicolumn{9}{|c|}{ Daily mean flow-by amounts, in $\mathrm{ft}^{3} / \mathrm{s}$, for indicated lakes, pumping rates, and target minimum flow-by multiples } \\
\hline & \multicolumn{9}{|c|}{ Pumping rate, in Mgal/d } \\
\hline & \multicolumn{3}{|c|}{1} & \multicolumn{3}{|c|}{2} & \multicolumn{3}{|c|}{3} \\
\hline & 1 & 2 & 3 & 1 & 2 & 3 & 1 & 2 & 3 \\
\hline & \multicolumn{9}{|c|}{ Atwood Lake } \\
\hline 75th percentile & 103.8 & 103.8 & 103.8 & 102.2 & 102.2 & 102.2 & 100.7 & 100.7 & 100.7 \\
\hline mean & 83.9 & 84.0 & 84.0 & 82.5 & 82.6 & 82.6 & 81.1 & 81.2 & 81.3 \\
\hline 50th percentile & 51.3 & 51.3 & 51.3 & 49.8 & 49.8 & 49.8 & 48.2 & 48.2 & 48.2 \\
\hline 25 th percentile & 11.5 & 11.5 & 11.5 & 9.9 & 9.9 & 9.9 & 8.4 & 8.4 & 8.4 \\
\hline 10th percentile & 4.7 & 4.7 & 4.7 & 3.1 & 3.1 & 4.5 & 1.6 & 3.0 & 4.5 \\
\hline 75th percentile & 86.5 & 86.5 & 86.5 & 84.9 & 84.9 & 84.9 & 83.4 & 83.4 & 83.4 \\
\hline mean & 57.5 & 57.6 & 57.7 & 56.2 & 56.4 & 56.6 & 55.1 & 55.3 & 55.5 \\
\hline 50th percentile & 22.9 & 22.9 & 22.9 & 21.4 & 21.4 & 21.4 & 19.8 & 19.8 & 19.8 \\
\hline 25 th percentile & 4.0 & 4.0 & 4.5 & 2.4 & 3.0 & 4.5 & 1.5 & 3.0 & 4.5 \\
\hline 10th percentile & 1.5 & 2.0 & 2.0 & 1.5 & 2.0 & 2.0 & 1.5 & 2.0 & 2.0 \\
\hline \multirow[t]{2}{*}{ 5th percentile } & 1.5 & 1.6 & 1.6 & 1.5 & 1.6 & 1.6 & 1.5 & 1.6 & 1.6 \\
\hline & \multicolumn{9}{|c|}{ Tappan Lake } \\
\hline 95th percentile & 361.5 & 361.5 & 361.5 & 359.9 & 359.9 & 359.9 & 358.4 & 358.4 & 358.4 \\
\hline
\end{tabular}


Table 9. Statistics of Atwood Lake, Ohio, daily mean flow-by amounts, by month, for indicated pumping rates and target minimum flow-by amounts.

[ $\mathrm{ft}^{3} / \mathrm{s}$, cubic foot per second; Mgal/d, million gallons per day]

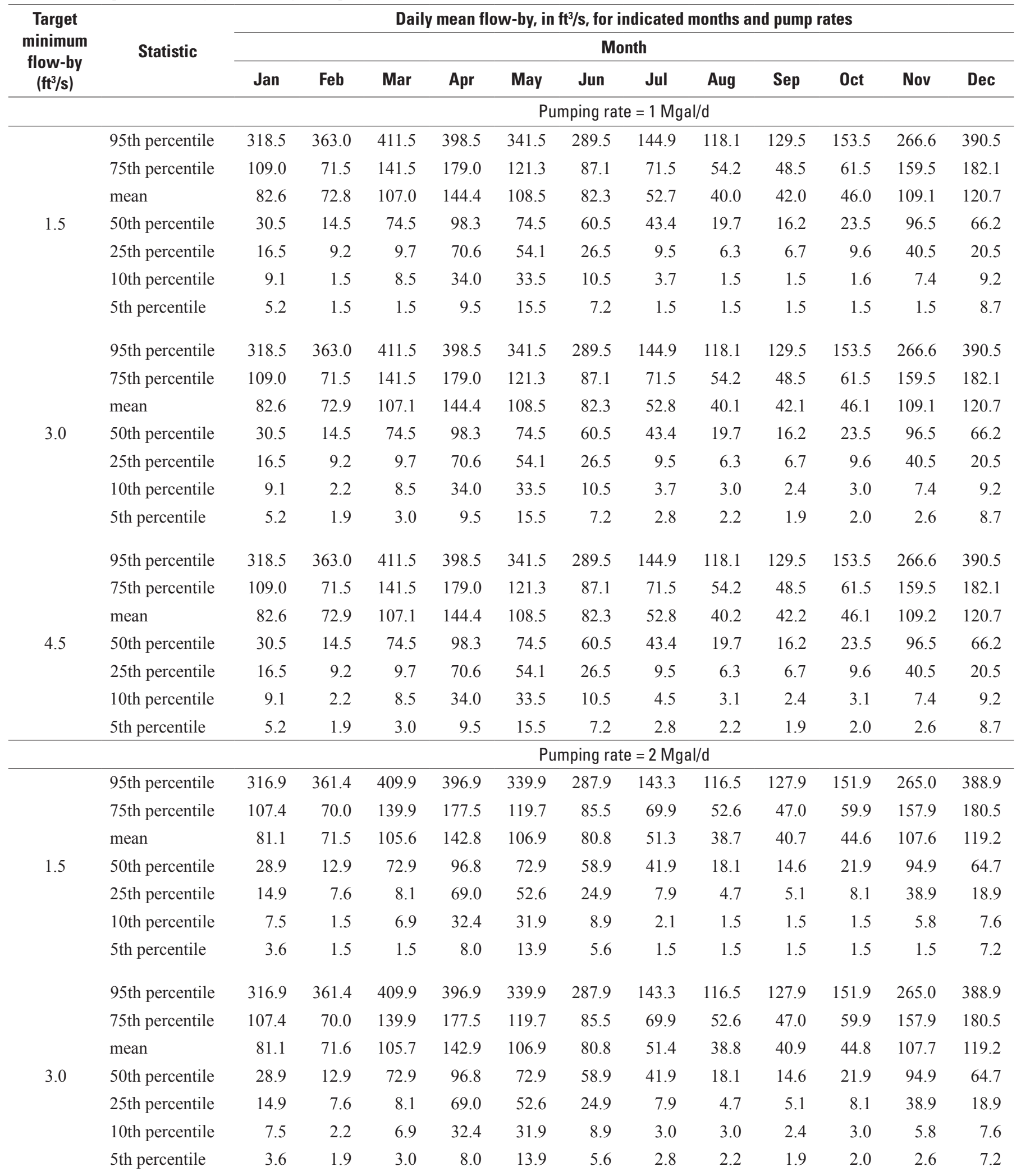


Table 9. Statistics of Atwood Lake, Ohio, daily mean flow-by amounts, by month, for indicated pumping rates and target minimum flow-by amounts.-Continued

$\left[\mathrm{ft}^{3} / \mathrm{s}\right.$, cubic foot per second; Mgal/d, million gallons per day]

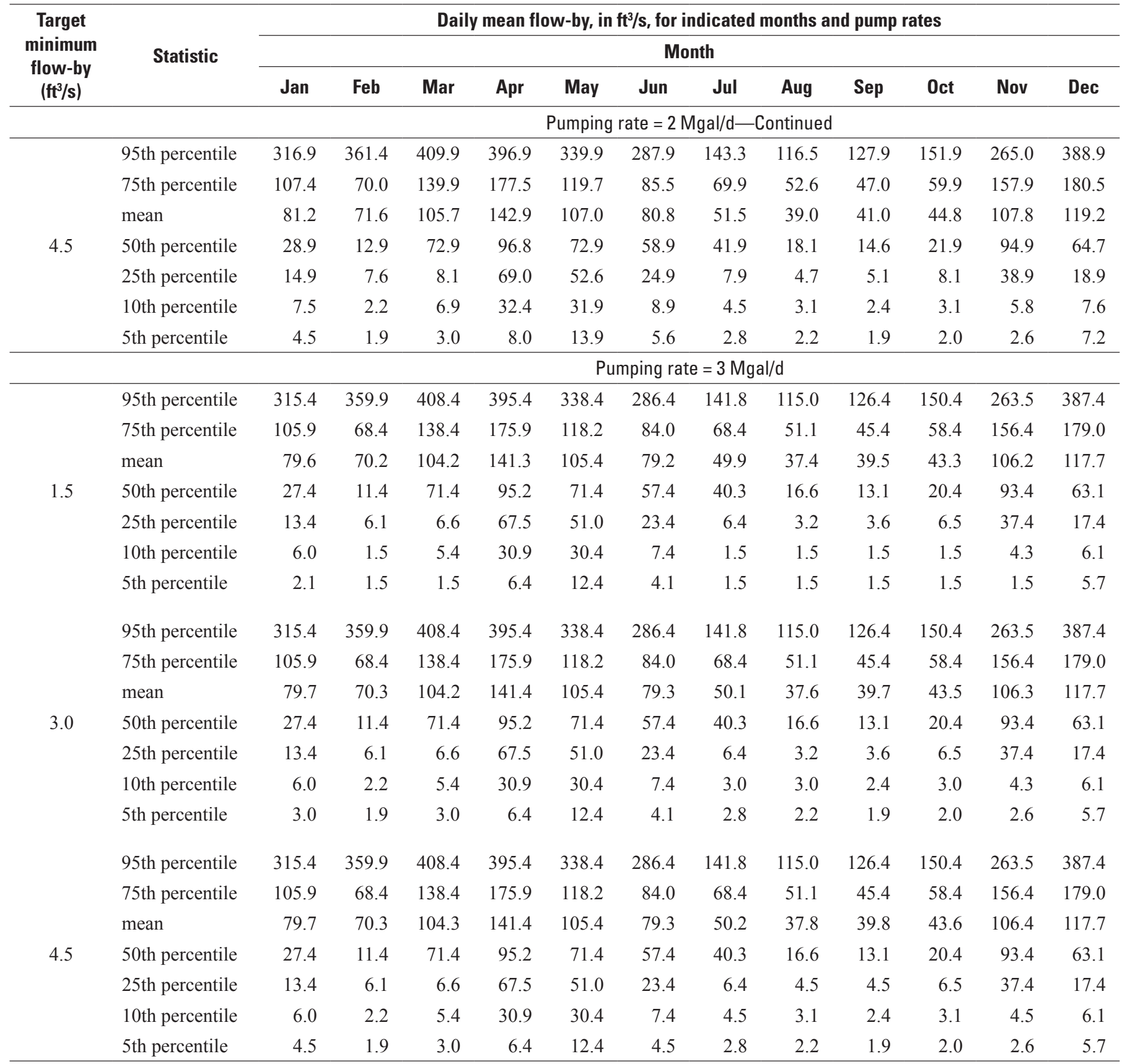


Table 10. Statistics of Leesville Lake, Ohio, daily mean flow-by amounts, by month, for indicated pumping rates and target minimum flow-by amounts.

$\left[\mathrm{ft}^{3} / \mathrm{s}\right.$, cubic foot per second; Mgal/d, million gallons per day $]$

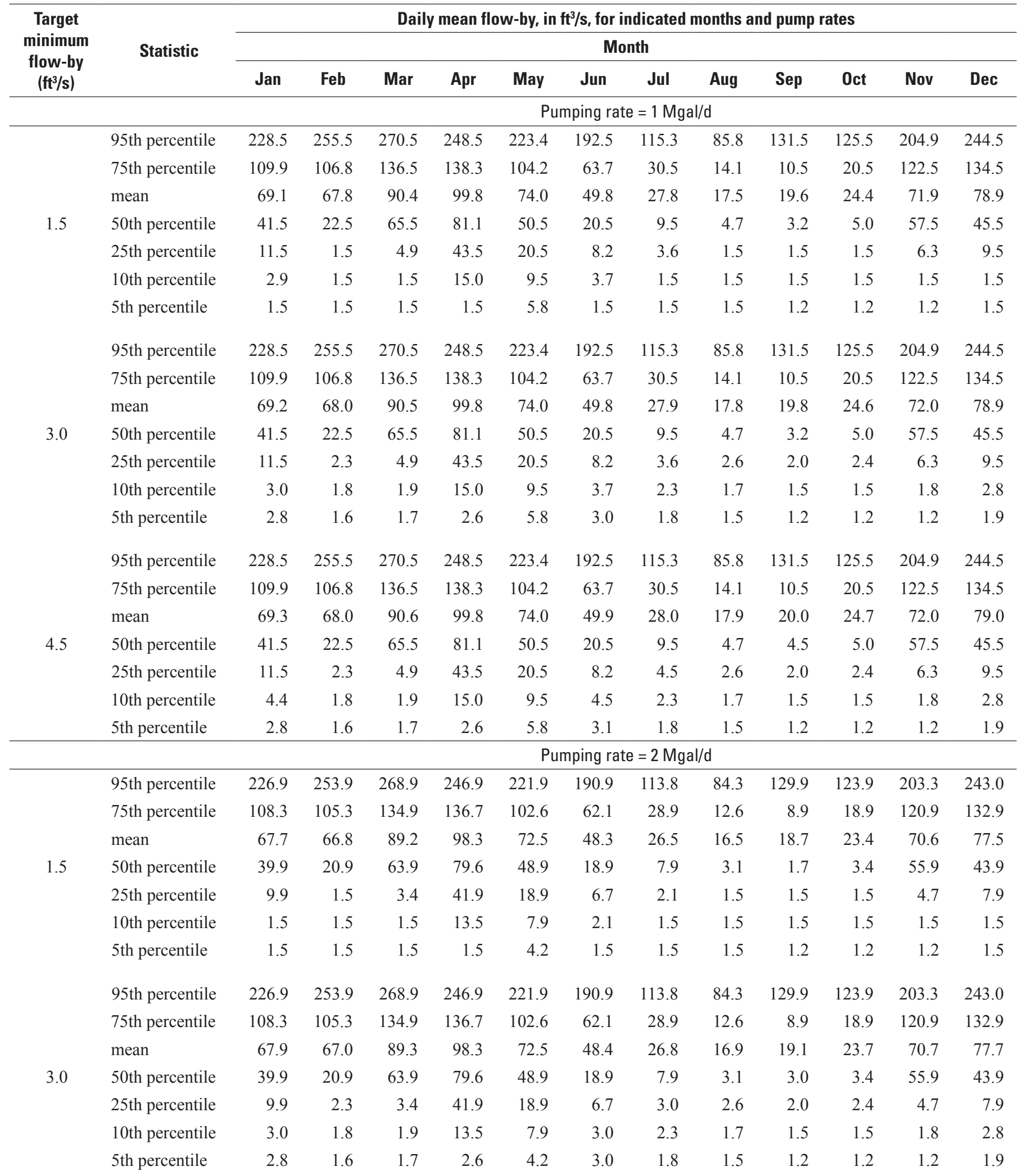


Table 10. Statistics of Leesville Lake, Ohio, daily mean flow-by amounts, by month, for indicated pumping rates and target minimum flow-by amounts.-Continued

\begin{tabular}{|c|c|c|c|c|c|c|c|c|c|c|c|c|c|}
\hline \multirow{2}{*}{$\begin{array}{c}\text { Target } \\
\text { minimum } \\
\text { flow-by } \\
\left(\mathrm{ft}^{3} / \mathrm{s}\right)\end{array}$} & \multirow[b]{2}{*}{ Statistic } & \multicolumn{12}{|c|}{ Daily mean flow-by, in $\mathrm{ft}^{3} / \mathrm{s}$, for indicated months and pump rates } \\
\hline & & \multicolumn{12}{|c|}{ Month } \\
\hline & & \multicolumn{12}{|c|}{ Pumping rate $=2 \mathrm{Mgal} / \mathrm{d}$-Continued } \\
\hline \multirow{6}{*}{4.5} & 95th percentile & 226.9 & 253.9 & 268.9 & 246.9 & 221.9 & 190.9 & 113.8 & 84.3 & 129.9 & 123.9 & 203.3 & 243.0 \\
\hline & mean & 68.0 & 67.1 & 89.4 & 98.4 & 72.5 & 48.5 & 27.0 & 17.2 & 19.4 & 24.0 & 70.8 & 77.8 \\
\hline & 50th percentile & 39.9 & 20.9 & 63.9 & 79.6 & 48.9 & 18.9 & 7.9 & 4.5 & 4.5 & 4.5 & 55.9 & 43.9 \\
\hline & 25 th percentile & 9.9 & 2.3 & 4.5 & 41.9 & 18.9 & 6.7 & 4.5 & 2.6 & 2.0 & 2.4 & 4.7 & 7.9 \\
\hline & 10th percentile & 4.4 & 1.8 & 1.9 & 13.5 & 7.9 & 4.5 & 2.3 & 1.7 & 1.5 & 1.5 & 1.8 & 2.8 \\
\hline & 5th percentile & 2.8 & 1.6 & 1.7 & 2.6 & 4.5 & 3.1 & 1.8 & 1.5 & 1.2 & 1.2 & 1.2 & 1.9 \\
\hline \multirow{5}{*}{1.5} & mean & 66.4 & 65.8 & 88.0 & 96.9 & 71.0 & 46.9 & 25.4 & 15.7 & 18.0 & 22.5 & 69.4 & 76.2 \\
\hline & 50th percentile & 38.4 & 19.4 & 62.4 & 78.0 & 47.4 & 17.4 & 6.4 & 1.6 & 1.5 & 1.9 & 54.4 & 42.4 \\
\hline & 25 th percentile & 8.4 & 1.5 & 1.9 & 40.4 & 17.4 & 5.1 & 1.5 & 1.5 & 1.5 & 1.5 & 3.2 & 6.4 \\
\hline & 10th percentile & 1.5 & 1.5 & 1.5 & 11.9 & 6.4 & 1.5 & 1.5 & 1.5 & 1.5 & 1.5 & 1.5 & 1.5 \\
\hline & 5 th percentile & 1.5 & 1.5 & 1.5 & 1.5 & 2.7 & 1.5 & 1.5 & 1.5 & 1.2 & 1.2 & 1.2 & 1.5 \\
\hline \multirow{3}{*}{3.0} & 95th percentile & 225.4 & 252.4 & 267.4 & 245.4 & 220.3 & 189.4 & 112.2 & 82.7 & 128.4 & 122.4 & 201.8 & 241.5 \\
\hline & 75th percentile & 106.8 & 103.7 & 133.4 & 135.2 & 101.1 & 60.6 & 27.4 & 11.0 & 7.4 & 17.4 & 119.4 & 131.4 \\
\hline & mean & 66.6 & 66.1 & 88.2 & 96.9 & 71.0 & 47.1 & 25.7 & 16.2 & 18.5 & 23.0 & 69.5 & 76.4 \\
\hline \multirow{6}{*}{4.5} & 75th percentile & 106.8 & 103.7 & 133.4 & 135.2 & 101.1 & 60.6 & 27.4 & 11.0 & 7.4 & 17.4 & 119.4 & 131.4 \\
\hline & mean & 66.7 & 66.2 & 88.3 & 96.9 & 71.1 & 47.3 & 26.0 & 16.6 & 18.8 & 23.4 & 69.7 & 76.6 \\
\hline & 50th percentile & 38.4 & 19.4 & 62.4 & 78.0 & 47.4 & 17.4 & 6.4 & 4.5 & 4.5 & 4.5 & 54.4 & 42.4 \\
\hline & 25 th percentile & 8.4 & 2.3 & 4.5 & 40.4 & 17.4 & 5.1 & 4.5 & 2.6 & 2.0 & 2.4 & 4.5 & 6.4 \\
\hline & 10th percentile & 4.4 & 1.8 & 1.9 & 11.9 & 6.4 & 4.5 & 2.3 & 1.7 & 1.5 & 1.5 & 1.8 & 2.8 \\
\hline & 5th percentile & 2.8 & 1.6 & 1.7 & 2.6 & 4.5 & 3.1 & 1.8 & 1.5 & 1.2 & 1.2 & 1.2 & 1.9 \\
\hline
\end{tabular}


Table 11. Statistics of Tappan Lake, Ohio, daily mean flow-by amounts, by month, for indicated pumping rates and target minimum flow-by amounts.

$\left[\mathrm{ft}^{3} / \mathrm{s}\right.$, cubic foot per second; Mgal/d, million gallons per day]

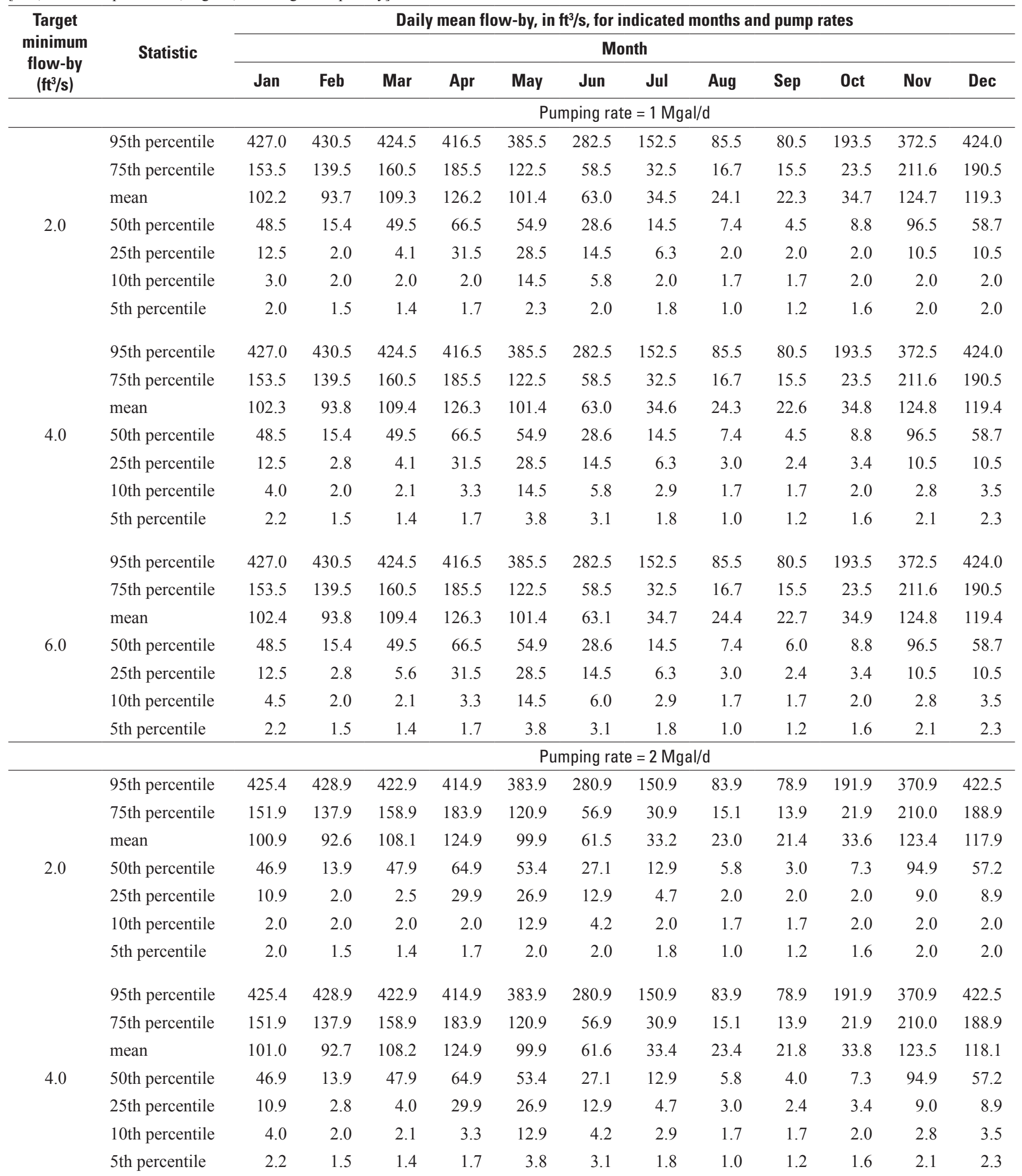


Table 11. Statistics of Tappan Lake, Ohio, daily mean flow-by amounts, by month, for indicated pumping rates and target minimum flow-by amounts.-Continued

[ft3/s, cubic foot per second; Mgal/d, million gallons per day]

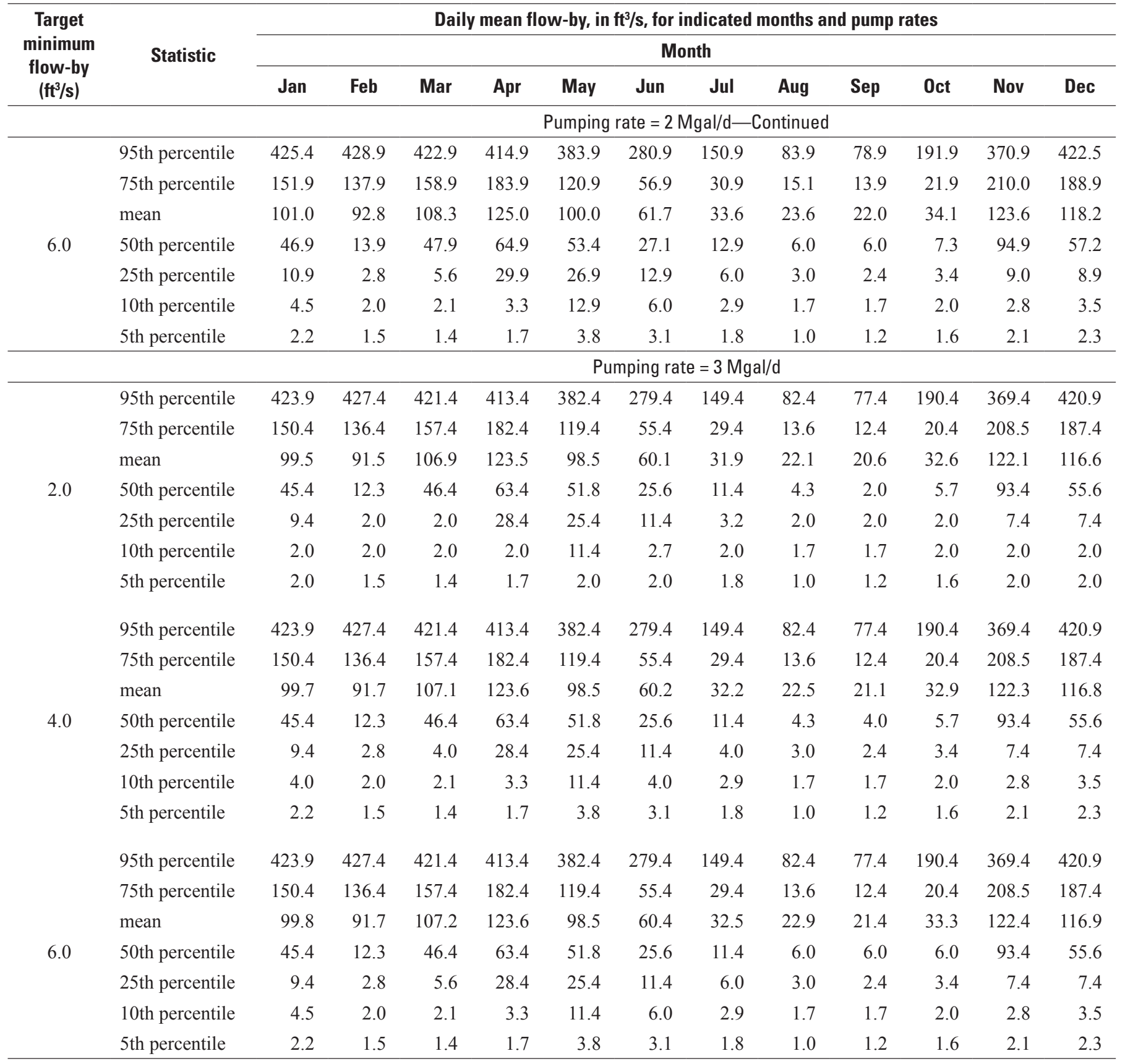


Table 12 shows the computed aggregate analytical-period flow-by statistics from table 8 reported as a percentage of the corresponding observed outflow statistics from table 6 . The cells of table 12 have been color-coded according to a gradient, where the maximum value in the table (100 percent) is colored dark green and the minimum value ( 27.3 percent) is colored red. Values that lie between these two extremes are graded in color from light green to dark orange as a function of their magnitude. The objective of coloring the table cells is to make it easier to visualize the conditions and flow percentiles that deviate most from the corresponding observed outflow statistics. Clearly, with the exception of some of the lower percentiles ( 10 percent and smaller), the flow-by amounts tend to represent an increasingly smaller proportion of the observed outflows as pumping rates are increased. Increasing the target minimum flow-by amount mitigates the effect of increased pumping for some order statistics. The reason that some low-percentile flow-by amounts were unchanged from observed outflows after increases in pump capacities and target minimum flow-by amounts is that the observed outflows were already less than or equal to the smallest flow-by amount considered, so no additional water was available for pumping and (or) to be reserved as flow-by.

Tables 13-15 show the computed monthly flow-by statistics from tables 9-11 reported as percentages of the corresponding observed outflow statistics from table 7 . Similar to table 12, the cells in these tables have been colored-coded according to a gradient, where the maximum value in each table is colored dark green and the minimum value is colored red. As was observed with the aggregate analytical-period results (table 12), with the exception of some of the lower percentiles, the monthly flow-by amounts tend to represent an increasingly smaller proportion of the observed outflows as pumping rates are increased. Clearly, for some order statistics, flow-by amounts tend to represent proportionally smaller amounts of the observed outflows in certain months (for example, JulyOctober) than in others. Increasing flow-by amounts mitigate some of these reductions in flow; however, that mitigation comes at the expense of smaller potential withdrawals.
Mass-curve data are reported for the Atwood, Leesville, and Tappan Lakes in appendix 1 (table 1-1). Figure 3 shows an example plot of the surplus-water mass curves for the Atwood, Leesville, and Tappan Lakes based on current target minimum outflows. The mass curve for Atwood Lake is based on 51 years of data whereas the mass curves for Leesville and Tappan Lakes are each based on 73 years of data. The slope of a line that connects the first and last point on a mass curve for a given lake in figure 3 represents the average daily surpluswater volume for that lake. It is evident from figure 3 that the Leesville Lake has an average daily surplus-water volume that is considerably smaller than that of the Atwood and Tappan Lakes. That seems reasonable given that the drainage area of the Leesville Lake is considerably smaller than that of the Atwood and Tappan Lakes.

\section{Limitations}

Direct use of the data presented in this report to make decisions about future water uses requires assumptions about the extent to which historical outflow characteristics will be representative of future outflow characteristics. Those assumptions could be in error depending on the degree to which there are changes in future climate or other factors that affect inflows to, or water losses from, the lakes.

Computed withdrawals represent maximum values given the combination of pumping rate and target minimum flow-by amounts, and assume that the observed outflow data are accurate. The ability to actually capture these maximum withdrawals will depend on how the pumps are operated, the maximum amount of storage for pumped water, and on the rate and (or) timing of removal of water from storage.

The term "surplus water," as used in this report, is not meant to imply judgment about the value of the water for any particular use, but is used merely to signify the amount of water that potentially is available for withdrawal while still meeting the minimum flow-by target immediately downstream from the lake. 
Table 12. Daily mean flow-by statistics for the Atwood, Leesville, and Tappan Lakes, Muskingum River Watershed, Ohio, expressed as a percentage of observed outflow statistics.

[Mgal/d, million gallons per day; minimum in-stream flow targets equal 1.5 cubic feet per second $\left(\mathrm{ft}^{3} / \mathrm{s}\right)$ for Atwood and Leesville Lakes and $2.0 \mathrm{ft}^{3} / \mathrm{s}$ for Tappan Lake; color scale is gradient from maximum value, in green, to minimum value, in red]

\begin{tabular}{|c|c|c|c|c|c|c|c|c|c|}
\hline \multirow{4}{*}{ Statistic } & \multicolumn{9}{|c|}{$\begin{array}{l}\text { Daily mean flow-by amounts expressed as a percentage of observed outflow statistics, for indicated lakes, } \\
\text { pumping rates, and minimum in-stream flow-target multiples }\end{array}$} \\
\hline & \multicolumn{9}{|c|}{ Pumping rate, in Mgal/d } \\
\hline & \multicolumn{9}{|c|}{ Minimum in-stream flow-target multiple } \\
\hline & 1 & 2 & 3 & 1 & 2 & 3 & 1 & 2 & 3 \\
\hline 75th percentile & $98.5 \%$ & $98.5 \%$ & $98.5 \%$ & $97.1 \%$ & $97.1 \%$ & $97.1 \%$ & $95.6 \%$ & $95.6 \%$ & $95.6 \%$ \\
\hline mean & $98.3 \%$ & $98.3 \%$ & $98.4 \%$ & $96.6 \%$ & $96.7 \%$ & $96.7 \%$ & $94.9 \%$ & $95.1 \%$ & $95.1 \%$ \\
\hline 50th percentile & $97.1 \%$ & $97.1 \%$ & $97.1 \%$ & $94.1 \%$ & $94.1 \%$ & $94.1 \%$ & $91.2 \%$ & $91.2 \%$ & $91.2 \%$ \\
\hline 25 th percentile & $88.1 \%$ & $88.1 \%$ & $88.1 \%$ & $76.2 \%$ & $76.2 \%$ & $76.2 \%$ & $64.3 \%$ & $64.3 \%$ & $64.3 \%$ \\
\hline 95th percentile & $99.3 \%$ & $99.3 \%$ & $99.3 \%$ & $98.6 \%$ & $98.6 \%$ & $98.6 \%$ & $97.9 \%$ & $97.9 \%$ & $97.9 \%$ \\
\hline 75th percentile & $98.2 \%$ & $98.2 \%$ & $98.2 \%$ & $96.5 \%$ & $96.5 \%$ & $96.5 \%$ & $94.7 \%$ & $94.7 \%$ & $94.7 \%$ \\
\hline mean & $97.7 \%$ & $97.9 \%$ & $98.0 \%$ & $95.6 \%$ & $95.9 \%$ & $96.1 \%$ & $93.6 \%$ & $94.0 \%$ & $94.4 \%$ \\
\hline 50th percentile & $93.7 \%$ & $93.7 \%$ & $93.7 \%$ & $87.3 \%$ & $87.3 \%$ & $87.3 \%$ & $81.0 \%$ & $81.0 \%$ & $81.0 \%$ \\
\hline 25 th percentile & $71.9 \%$ & $71.9 \%$ & $81.8 \%$ & $43.7 \%$ & $54.5 \%$ & $81.8 \%$ & $27.3 \%$ & $54.5 \%$ & $81.8 \%$ \\
\hline 10th percentile & $75.0 \%$ & $100.0 \%$ & $100.0 \%$ & $75.0 \%$ & $100.0 \%$ & $100.0 \%$ & $75.0 \%$ & $100.0 \%$ & $100.0 \%$ \\
\hline \multirow[t]{2}{*}{5 th percentile } & $93.8 \%$ & $100.0 \%$ & $100.0 \%$ & $93.8 \%$ & $100.0 \%$ & $100.0 \%$ & $93.8 \%$ & $100.0 \%$ & $100.0 \%$ \\
\hline & \multicolumn{9}{|c|}{ Tappan Lake } \\
\hline 95th percentile & $99.6 \%$ & $99.6 \%$ & $99.6 \%$ & $99.1 \%$ & $99.1 \%$ & $99.1 \%$ & $98.7 \%$ & $98.7 \%$ & $98.7 \%$ \\
\hline 5th percentile & $100.0 \%$ & $100.0 \%$ & $100.0 \%$ & $100.0 \%$ & $100.0 \%$ & $100.0 \%$ & $100.0 \%$ & $100.0 \%$ & $100.0 \%$ \\
\hline
\end{tabular}


Table 13. Monthly statistics of Atwood Lake, Ohio, daily mean flow-by amounts for indicated pumpina rates and target minimum flow-by amounts, expressed as a percentage of corresponding statistic based on observed outflows.

[fts $/ \mathrm{s}$, cubic foot per second; Mgal/d, million gallons per day; color scale is gradient from maximum value, in green, to minimum value, in red]

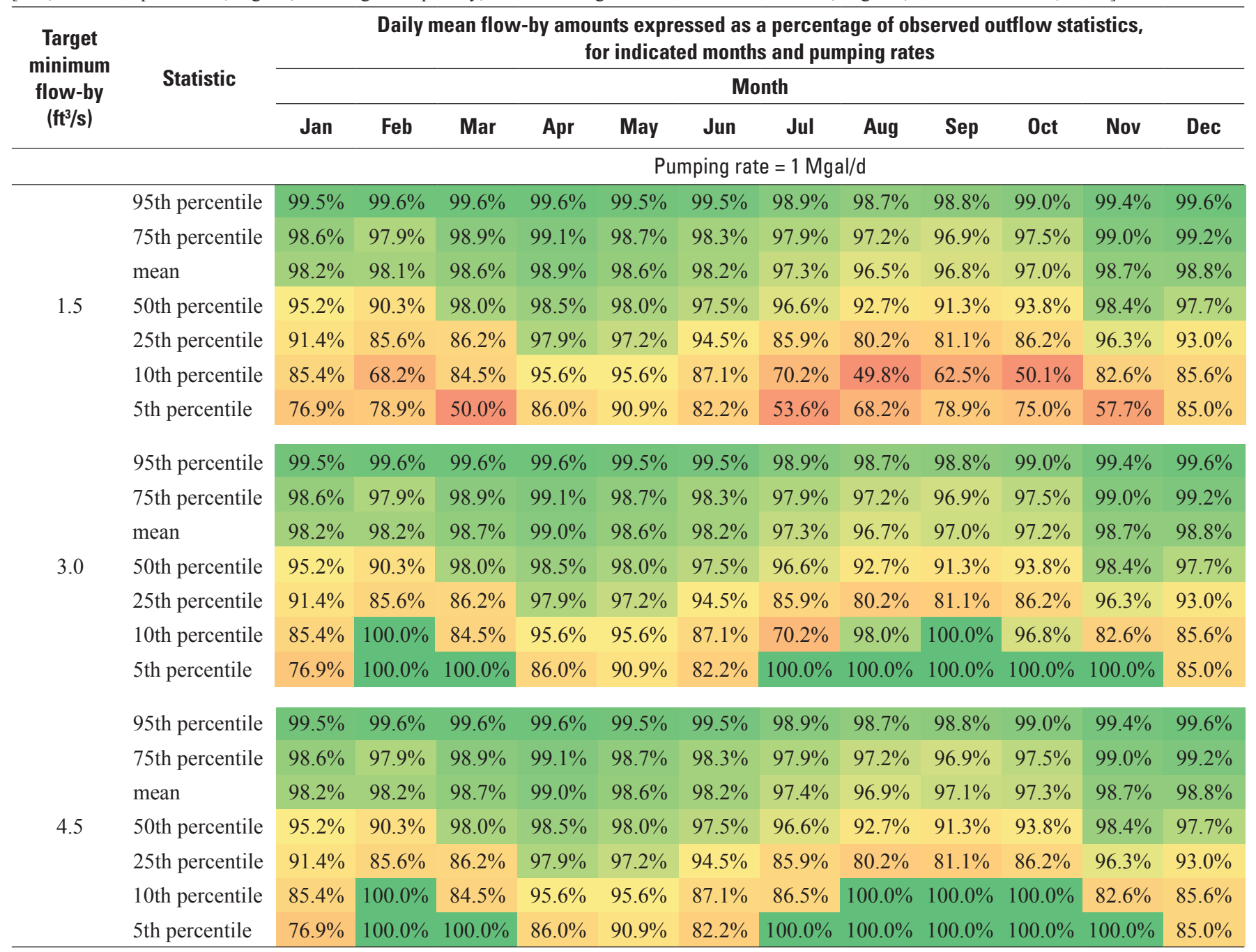

Pumping rate $=2 \mathrm{Mgal} / \mathrm{d}$

$\begin{array}{lllllllllllll}\text { 95th percentile } & 99.0 \% & 99.2 \% & 99.3 \% & 99.2 \% & 99.1 \% & 98.9 \% & 97.9 \% & 97.4 \% & 97.6 \% & 98.0 \% & 98.8 \% & 99.2 \%\end{array}$

75 th percentile

\begin{tabular}{|llllllllllll}
$97.2 \%$ & $95.8 \%$ & $97.8 \%$ & $98.3 \%$ & $97.5 \%$ & $96.5 \%$ & $95.8 \%$ & $94.4 \%$ & $93.8 \%$ & $95.1 \%$ & $98.1 \%$ & $98.3 \%$
\end{tabular}

mean

1.5 50th percentile

$\begin{array}{llllllllllll}96.4 \% & 96.3 \% & 97.3 \% & 97.9 \% & 97.2 \% & 96.3 \% & 94.6 \% & 93.2 \% & 93.8 \% & 94.1 \% & 97.4 \% & 97.5 \%\end{array}$

25 th percentile

$\begin{array}{lllllllllllll}90.3 \% & 80.7 \% & 95.9 \% & 96.9 \% & 95.9 \% & 95.0 \% & 93.1 \% & 85.4 \% & 82.5 \% & 87.6 \% & 96.8 \% & 95.4 \%\end{array}$

10th percentile

\begin{tabular}{|l|l|l|l|l|l|l|l|l|l|l|l}
$82.8 \%$ & $71.1 \%$ & $72.4 \%$ & $95.7 \%$ & $94.4 \%$ & $88.9 \%$ & $71.9 \%$ & $60.3 \%$ & $62.3 \%$ & $72.3 \%$ & $92.6 \%$ & $85.9 \%$
\end{tabular}

5 th percentile

$70.8 \% \quad 68.2 \% \quad 69.1 \% \quad 91.3$

\begin{tabular}{|l|l|l|l|l|l|l|l|l|l|l|l}
$53.8 \%$ & $78.9 \%$ & $50.0 \%$ & $72.1 \%$ & $81.8 \%$ & $64.4 \%$ & $53.6 \%$ & $68.2 \%$ & $78.9 \%$ & $75.0 \%$ & $57.7 \%$ & $69.9 \%$
\end{tabular}

95th percentile

75th percentile

$\begin{array}{llllllllllll}99.0 \% & 99.2 \% & 99.3 \% & 99.2 \% & 99.1 \% & 98.9 \% & 97.9 \% & 97.4 \% & 97.6 \% & 98.0 \% & 98.8 \% & 99.2 \%\end{array}$

mean

3.0 50th percentile

$97.2 \% \quad 95.8 \% \quad 97.8 \% \quad 98$.

$\begin{array}{llllllllllll}96.5 \% & 96.5 \% & 97.4 \% & 97.9 \% & 97.2 \% & 96.4 \% & 94.8 \% & 93.6 \% & 94.2 \% & 94.4 \% & 97.4 \% & 97.6 \%\end{array}$

25 th percentile

$90.3 \% \quad 80.7 \% \quad 95.9 \% \quad 96.9$

10th percentile

$\begin{array}{llll}82.8 \% & 71.1 \% & 72.4 \% & 95.7\end{array}$

$\begin{array}{lllll}70.8 \% & 100.0 \% & 69.1 \% & 91 . & \end{array}$

$6.9 \% \quad 95.9 \%$

$95.0 \% \quad 93.1 \% \quad 85.4 \%$

$82.5 \% \quad 87$.

5th percentile

$\begin{array}{llllllllllllll}53.8 \% & 100.0 \% & 100.0 \% & 72.1 \% & 81.8 \% & 64.4 \% & 100.0 \% & 100.0 \% & 100.0 \% & 100.0 \% & 100.0 \% & 69.9 \%\end{array}$ 
Table 13. Monthly statistics of Atwood Lake, Ohio, daily mean flow-by amounts for indicated pumping rates and target minimum flow-by amounts, expressed as a percentage of corresponding statistic based on observed outflows.-Continued

[ $\mathrm{ft}^{3} / \mathrm{s}$, cubic foot per second; Mgal/d, million gallons per day; color scale is gradient from maximum value, in green, to minimum value, in red]

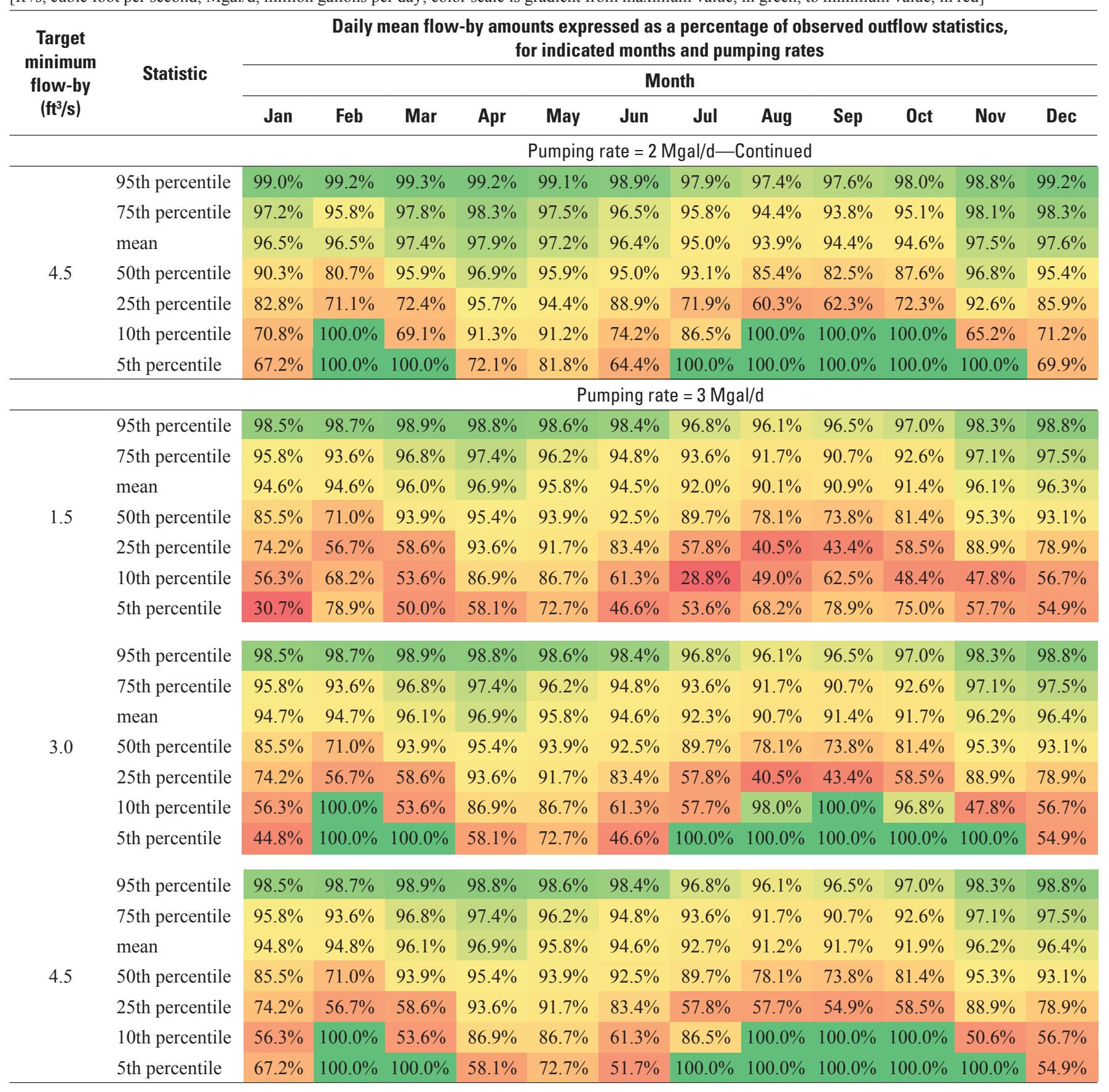


Table 14. Monthly statistics of Leesville Lake, Ohio, daily mean flow-by amounts for indicated pumping rates and target minimum flow-by amounts, expressed as a percentage of corresponding statistic based on observed outflows.

[ $\mathrm{ft}^{3} / \mathrm{s}$, cubic foot per second; Mgal/d, million gallons per day; color scale is gradient from maximum value, in green, to minimum value, in red]

\begin{tabular}{|c|c|c|c|c|c|c|c|c|c|c|c|c|c|}
\hline \multirow{2}{*}{$\begin{array}{c}\text { Target } \\
\text { minimum } \\
\text { flow-by } \\
\left(\mathrm{ft}^{3} / \mathrm{s}\right)\end{array}$} & \multirow[b]{2}{*}{ Statistic } & \multicolumn{12}{|c|}{$\begin{array}{l}\text { Daily mean flow-by amounts expressed as a percentage of observed outflow statistics, } \\
\text { for indicated months and pumping rates }\end{array}$} \\
\hline & & \multicolumn{12}{|c|}{ Month } \\
\hline & & \multicolumn{12}{|c|}{ Pumping rate $=1 \mathrm{Mgal} / \mathrm{d}$} \\
\hline \multirow{6}{*}{1.5} & 95th percentile & $99.3 \%$ & $99.4 \%$ & $99.4 \%$ & $99.4 \%$ & $99.3 \%$ & $99.2 \%$ & $98.7 \%$ & $98.2 \%$ & $98.8 \%$ & $98.8 \%$ & $99.3 \%$ & $99.4 \%$ \\
\hline & mean & $97.9 \%$ & $98.2 \%$ & $98.5 \%$ & $98.5 \%$ & $98.0 \%$ & $97.1 \%$ & $95.2 \%$ & $93.4 \%$ & $94.6 \%$ & $95.3 \%$ & $98.1 \%$ & $98.2 \%$ \\
\hline & 50th percentile & $96.4 \%$ & $93.6 \%$ & $97.7 \%$ & $98.1 \%$ & $97.0 \%$ & $93.0 \%$ & $85.9 \%$ & $75.0 \%$ & $67.5 \%$ & $76.2 \%$ & $97.4 \%$ & $96.7 \%$ \\
\hline & 25 th percentile & $88.1 \%$ & $64.4 \%$ & $76.2 \%$ & $96.6 \%$ & $93.0 \%$ & $84.2 \%$ & $70.0 \%$ & $57.7 \%$ & $75.0 \%$ & $62.5 \%$ & $80.2 \%$ & $85.9 \%$ \\
\hline & 10th percentile & $64.8 \%$ & $83.3 \%$ & $78.9 \%$ & $90.7 \%$ & $85.9 \%$ & $70.5 \%$ & $65.2 \%$ & $88.2 \%$ & $100.0 \%$ & $100.0 \%$ & $83.3 \%$ & $53.6 \%$ \\
\hline & 5 th percentile & $53.6 \%$ & $93.8 \%$ & $88.2 \%$ & $57.7 \%$ & $78.8 \%$ & $49.4 \%$ & $83.3 \%$ & $100.0 \%$ & $100.0 \%$ & $100.0 \%$ & $100.0 \%$ & $78.1 \%$ \\
\hline \multirow{5}{*}{3.0} & mean & $98.0 \%$ & $98.5 \%$ & $98.7 \%$ & $98.6 \%$ & $98.0 \%$ & $97.2 \%$ & $95.7 \%$ & $94.5 \%$ & $95.8 \%$ & $96.0 \%$ & $98.3 \%$ & $98.3 \%$ \\
\hline & 50th percentile & $96.4 \%$ & $93.6 \%$ & $97.7 \%$ & $98.1 \%$ & $97.0 \%$ & $93.0 \%$ & $85.9 \%$ & $75.0 \%$ & $67.5 \%$ & $76.2 \%$ & $97.4 \%$ & $96.7 \%$ \\
\hline & 25 th percentile & $88.1 \%$ & $100.0 \%$ & $76.2 \%$ & $96.6 \%$ & $93.0 \%$ & $84.2 \%$ & $70.0 \%$ & $100.0 \%$ & $100.0 \%$ & $100.0 \%$ & $80.2 \%$ & $85.9 \%$ \\
\hline & 10th percentile & $68.2 \%$ & $100.0 \%$ & $100.0 \%$ & $90.7 \%$ & $85.9 \%$ & $70.5 \%$ & $100.0 \%$ & $100.0 \%$ & $100.0 \%$ & $100.0 \%$ & $100.0 \%$ & $100.0 \%$ \\
\hline & 5 th percentile & $100.0 \%$ & $100.0 \%$ & $100.0 \%$ & $100.0 \%$ & $78.8 \%$ & $98.1 \%$ & $100.0 \%$ & $100.0 \%$ & $100.0 \%$ & $100.0 \%$ & $100.0 \%$ & $100.0 \%$ \\
\hline \multirow{3}{*}{4.5} & 95th percentile & $99.3 \%$ & $99.4 \%$ & $99.4 \%$ & $99.4 \%$ & $99.3 \%$ & $99.2 \%$ & $98.7 \%$ & $98.2 \%$ & $98.8 \%$ & $98.8 \%$ & $99.3 \%$ & $99.4 \%$ \\
\hline & 75th percentile & $98.6 \%$ & $98.6 \%$ & $98.9 \%$ & $98.9 \%$ & $98.5 \%$ & $97.6 \%$ & $95.2 \%$ & $90.1 \%$ & $87.1 \%$ & $93.0 \%$ & $98.8 \%$ & $98.9 \%$ \\
\hline & mean & $98.1 \%$ & $98.6 \%$ & $98.7 \%$ & $98.6 \%$ & $98.0 \%$ & $97.3 \%$ & $96.1 \%$ & $95.4 \%$ & $96.5 \%$ & $96.6 \%$ & $98.3 \%$ & $98.4 \%$ \\
\hline
\end{tabular}

Pumping rate $=2 \mathrm{Mgal} / \mathrm{d}$

\begin{tabular}{|c|c|c|c|c|c|c|c|c|c|c|c|c|c|}
\hline \multirow{7}{*}{1.5} & 95th percentile & $98.7 \%$ & $98.8 \%$ & $98.9 \%$ & $98.8 \%$ & $98.6 \%$ & $98.4 \%$ & $97.4 \%$ & $96.5 \%$ & $97.7 \%$ & $97.6 \%$ & $98.5 \%$ & $98.7 \%$ \\
\hline & 75 th percentile & $97.2 \%$ & $97.1 \%$ & $97.8 \%$ & $97.8 \%$ & $97.1 \%$ & $95.3 \%$ & $90.3 \%$ & $80.2 \%$ & $74.2 \%$ & $85.9 \%$ & $97.5 \%$ & $97.7 \%$ \\
\hline & mean & $95.9 \%$ & $96.7 \%$ & $97.2 \%$ & $97.1 \%$ & $96.1 \%$ & $94.3 \%$ & $90.9 \%$ & $87.9 \%$ & $90.4 \%$ & $91.4 \%$ & $96.4 \%$ & $96.5 \%$ \\
\hline & 50th percentile & $92.8 \%$ & $87.1 \%$ & $95.4 \%$ & $96.3 \%$ & $94.0 \%$ & $85.9 \%$ & $71.9 \%$ & $50.1 \%$ & $34.9 \%$ & $52.4 \%$ & $94.8 \%$ & $93.4 \%$ \\
\hline & 25 th percentile & $76.2 \%$ & $64.4 \%$ & $52.4 \%$ & $93.1 \%$ & $85.9 \%$ & $68.3 \%$ & $39.9 \%$ & $57.7 \%$ & $75.0 \%$ & $62.5 \%$ & $60.3 \%$ & $71.9 \%$ \\
\hline & 10th percentile & $34.1 \%$ & $83.3 \%$ & $78.9 \%$ & $81.3 \%$ & $71.9 \%$ & $41.0 \%$ & $65.2 \%$ & $88.2 \%$ & $100.0 \%$ & $100.0 \%$ & $83.3 \%$ & $53.6 \%$ \\
\hline & 5 th percentile & $53.6 \%$ & $93.8 \%$ & $88.2 \%$ & $57.7 \%$ & $57.6 \%$ & $49.1 \%$ & $83.3 \%$ & $100.0 \%$ & $100.0 \%$ & $100.0 \%$ & $100.0 \%$ & $78.1 \%$ \\
\hline \multirow{7}{*}{3.0} & 95th percentile & $98.7 \%$ & $98.8 \%$ & $98.9 \%$ & $98.8 \%$ & $98.6 \%$ & $98.4 \%$ & $97.4 \%$ & $96.5 \%$ & $97.7 \%$ & $97.6 \%$ & $98.5 \%$ & $98.7 \%$ \\
\hline & 75th percentile & $97.2 \%$ & $97.1 \%$ & $97.8 \%$ & $97.8 \%$ & $97.1 \%$ & $95.3 \%$ & $90.3 \%$ & $80.2 \%$ & $74.2 \%$ & $85.9 \%$ & $97.5 \%$ & $97.7 \%$ \\
\hline & mean & $96.1 \%$ & $97.1 \%$ & $97.4 \%$ & $97.1 \%$ & $96.1 \%$ & $94.5 \%$ & $91.7 \%$ & $90.0 \%$ & $92.3 \%$ & $92.6 \%$ & $96.6 \%$ & $96.7 \%$ \\
\hline & 50th percentile & $92.8 \%$ & $87.1 \%$ & $95.4 \%$ & $96.3 \%$ & $94.0 \%$ & $85.9 \%$ & $71.9 \%$ & $50.1 \%$ & $63.1 \%$ & $52.4 \%$ & $94.8 \%$ & $93.4 \%$ \\
\hline & 25 th percentile & $76.2 \%$ & $100.0 \%$ & $52.4 \%$ & $93.1 \%$ & $85.9 \%$ & $68.3 \%$ & $58.3 \%$ & $100.0 \%$ & $100.0 \%$ & $100.0 \%$ & $60.3 \%$ & $71.9 \%$ \\
\hline & 10th percentile & $68.2 \%$ & $100.0 \%$ & $100.0 \%$ & $81.3 \%$ & $71.9 \%$ & $57.2 \%$ & $100.0 \%$ & $100.0 \%$ & $100.0 \%$ & $100.0 \%$ & $100.0 \%$ & $100.0 \%$ \\
\hline & 5th percentile & $100.0 \%$ & $100.0 \%$ & $100.0 \%$ & $100.0 \%$ & $57.6 \%$ & $98.1 \%$ & $100.0 \%$ & $100.0 \%$ & $100.0 \%$ & $100.0 \%$ & $100.0 \%$ & $100.0 \%$ \\
\hline
\end{tabular}


Table 14. Monthly statistics of Leesville Lake, Ohio, daily mean flow-by amounts for indicated pumping rates and target minimum flow-by amounts, expressed as a percentage of corresponding statistic based on observed outflows.-Continued

[ $\mathrm{ft}^{3} / \mathrm{s}$, cubic foot per second; Mgal/d, million gallons per day; color scale is gradient from maximum value, in green, to minimum value, in red]

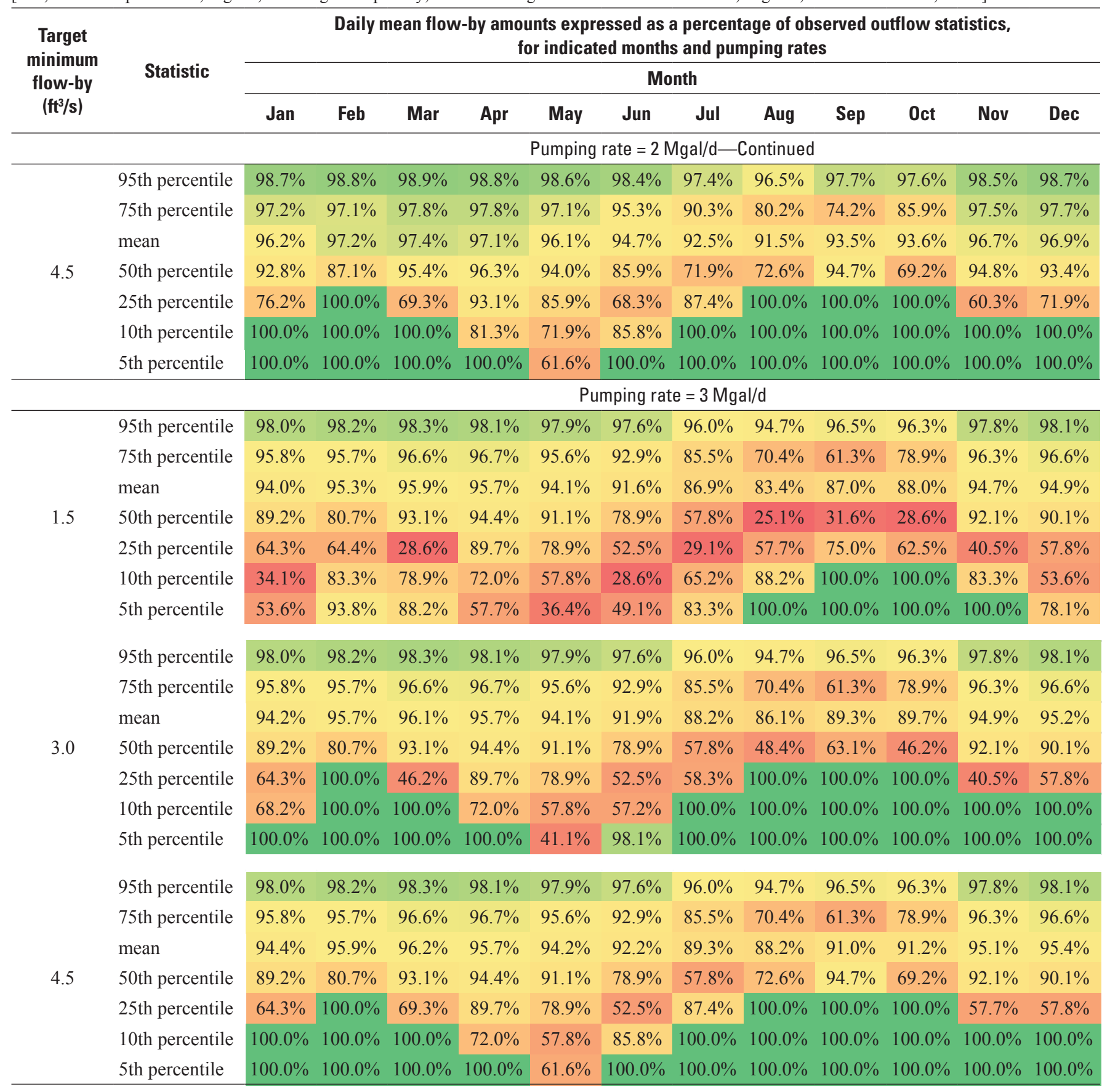


Table 15. Monthly statistics of Tappan Lake, Ohio, daily mean flow-by amounts for indicated pumping rates and target minimum flow-by amounts, expressed as a percentage of corresponding statistic based on observed outflows.

[ $\mathrm{ft}^{3} / \mathrm{s}$, cubic foot per second; Mgal/d, million gallons per day; color scale is gradient from maximum value, in green, to minimum value, in red]

\begin{tabular}{|c|c|c|c|c|c|c|c|c|c|c|c|c|c|}
\hline \multirow{2}{*}{$\begin{array}{c}\text { Target } \\
\text { minimum } \\
\text { flow-by } \\
\left(\mathrm{ft}^{3} / \mathrm{s}\right)\end{array}$} & \multirow[b]{2}{*}{ Statistic } & \multicolumn{12}{|c|}{$\begin{array}{l}\text { Daily mean flow-by amounts expressed as a percentage of observed outflow statistics, } \\
\text { for indicated months and pumping rates }\end{array}$} \\
\hline & & \multicolumn{12}{|c|}{ Month } \\
\hline & & \multicolumn{12}{|c|}{ Pumping rate $=1 \mathrm{Mgal} / \mathrm{d}$} \\
\hline \multirow{6}{*}{2.0} & 95th percentile & $99.6 \%$ & $99.6 \%$ & $99.6 \%$ & $99.6 \%$ & $99.6 \%$ & $99.5 \%$ & $99.0 \%$ & $98.2 \%$ & $98.1 \%$ & $99.2 \%$ & $99.6 \%$ & $99.6 \%$ \\
\hline & mean & $98.6 \%$ & $98.7 \%$ & $98.8 \%$ & $98.9 \%$ & $98.6 \%$ & $97.7 \%$ & $96.1 \%$ & $95.2 \%$ & $95.3 \%$ & $96.6 \%$ & $98.9 \%$ & $98.8 \%$ \\
\hline & 50th percentile & $96.9 \%$ & $90.9 \%$ & $97.0 \%$ & $97.7 \%$ & $97.3 \%$ & $94.9 \%$ & $90.3 \%$ & $82.7 \%$ & $74.6 \%$ & $85.1 \%$ & $98.4 \%$ & $97.4 \%$ \\
\hline & 25 th percentile & $88.9 \%$ & $71.4 \%$ & $72.4 \%$ & $95.3 \%$ & $94.8 \%$ & $90.3 \%$ & $80.2 \%$ & $66.7 \%$ & $83.3 \%$ & $58.8 \%$ & $87.2 \%$ & $87.1 \%$ \\
\hline & 10th percentile & $65.6 \%$ & $100.0 \%$ & $95.2 \%$ & $59.8 \%$ & $90.3 \%$ & $78.8 \%$ & $69.0 \%$ & $100.0 \%$ & $100.0 \%$ & $100.0 \%$ & $71.4 \%$ & $57.1 \%$ \\
\hline & 5th percentile & $90.9 \%$ & $100.0 \%$ & $100.0 \%$ & $100.0 \%$ & $59.3 \%$ & $64.5 \%$ & $100.0 \%$ & $100.0 \%$ & $100.0 \%$ & $100.0 \%$ & $95.2 \%$ & $87.0 \%$ \\
\hline \multirow{5}{*}{4.0} & mean & $98.7 \%$ & $98.8 \%$ & $98.9 \%$ & $98.9 \%$ & $98.6 \%$ & $97.8 \%$ & $96.4 \%$ & $96.0 \%$ & $96.3 \%$ & $97.0 \%$ & $99.0 \%$ & $98.9 \%$ \\
\hline & 50th percentile & $96.9 \%$ & $90.9 \%$ & $97.0 \%$ & $97.7 \%$ & $97.3 \%$ & $94.9 \%$ & $90.3 \%$ & $82.7 \%$ & $74.6 \%$ & $85.1 \%$ & $98.4 \%$ & $97.4 \%$ \\
\hline & 25th percentile & $88.9 \%$ & $100.0 \%$ & $72.4 \%$ & $95.3 \%$ & $94.8 \%$ & $90.3 \%$ & $80.2 \%$ & $100.0 \%$ & $100.0 \%$ & $100.0 \%$ & $87.2 \%$ & $87.1 \%$ \\
\hline & 10th percentile & $88.9 \%$ & $100.0 \%$ & $100.0 \%$ & $100.0 \%$ & $90.3 \%$ & $78.8 \%$ & $100.0 \%$ & $100.0 \%$ & $100.0 \%$ & $100.0 \%$ & $100.0 \%$ & $100.0 \%$ \\
\hline & 5th percentile & $100.0 \%$ & $100.0 \%$ & $100.0 \%$ & $100.0 \%$ & $100.0 \%$ & $100.0 \%$ & $100.0 \%$ & $100.0 \%$ & $100.0 \%$ & $100.0 \%$ & $100.0 \%$ & $100.0 \%$ \\
\hline \multirow{3}{*}{6.0} & 95th percentile & $99.6 \%$ & $99.6 \%$ & $99.6 \%$ & $99.6 \%$ & $99.6 \%$ & $99.5 \%$ & $99.0 \%$ & $98.2 \%$ & $98.1 \%$ & $99.2 \%$ & $99.6 \%$ & $99.6 \%$ \\
\hline & 75th percentile & $99.0 \%$ & $98.9 \%$ & $99.0 \%$ & $99.2 \%$ & $98.8 \%$ & $97.4 \%$ & $95.4 \%$ & $91.5 \%$ & $90.9 \%$ & $93.8 \%$ & $99.3 \%$ & $99.2 \%$ \\
\hline & mean & $98.7 \%$ & $98.9 \%$ & $99.0 \%$ & $98.9 \%$ & $98.6 \%$ & $97.8 \%$ & $96.7 \%$ & $96.5 \%$ & $96.8 \%$ & $97.3 \%$ & $99.0 \%$ & $98.9 \%$ \\
\hline \multirow{6}{*}{2.0} & 75th percentile & $98.0 \%$ & $97.8 \%$ & $98.1 \%$ & $98.3 \%$ & $97.5 \%$ & $94.8 \%$ & $90.9 \%$ & $83.0 \%$ & $81.8 \%$ & $87.6 \%$ & $98.5 \%$ & $98.4 \%$ \\
\hline & mean & $97.3 \%$ & $97.6 \%$ & $97.8 \%$ & $97.8 \%$ & $97.1 \%$ & $95.5 \%$ & $92.4 \%$ & $91.0 \%$ & $91.4 \%$ & $93.5 \%$ & $97.8 \%$ & $97.7 \%$ \\
\hline & 50th percentile & $93.8 \%$ & $81.8 \%$ & $93.9 \%$ & $95.4 \%$ & $94.5 \%$ & $89.8 \%$ & $80.7 \%$ & $65.3 \%$ & $49.2 \%$ & $70.1 \%$ & $96.8 \%$ & $94.9 \%$ \\
\hline & 25th percentile & $77.9 \%$ & $71.4 \%$ & $44.7 \%$ & $90.6 \%$ & $89.7 \%$ & $80.7 \%$ & $60.3 \%$ & $66.7 \%$ & $83.3 \%$ & $58.8 \%$ & $74.3 \%$ & $74.2 \%$ \\
\hline & 10th percentile & $44.4 \%$ & $100.0 \%$ & $95.2 \%$ & $59.8 \%$ & $80.7 \%$ & $57.6 \%$ & $69.0 \%$ & $100.0 \%$ & $100.0 \%$ & $100.0 \%$ & $71.4 \%$ & $57.1 \%$ \\
\hline & 5 th percentile & $90.9 \%$ & $100.0 \%$ & $100.0 \%$ & $100.0 \%$ & $52.6 \%$ & $64.5 \%$ & $100.0 \%$ & $100.0 \%$ & $100.0 \%$ & $100.0 \%$ & $95.2 \%$ & $87.0 \%$ \\
\hline \multirow{7}{*}{4.0} & 95th percentile & $99.3 \%$ & $99.3 \%$ & $99.3 \%$ & $99.3 \%$ & $99.2 \%$ & $98.9 \%$ & $98.0 \%$ & $96.4 \%$ & $96.2 \%$ & $98.4 \%$ & $99.2 \%$ & $99.3 \%$ \\
\hline & 75th percentile & $98.0 \%$ & $97.8 \%$ & $98.1 \%$ & $98.3 \%$ & $97.5 \%$ & $94.8 \%$ & $90.9 \%$ & $83.0 \%$ & $81.8 \%$ & $87.6 \%$ & $98.5 \%$ & $98.4 \%$ \\
\hline & mean & $97.4 \%$ & $97.7 \%$ & $97.9 \%$ & $97.9 \%$ & $97.2 \%$ & $95.6 \%$ & $93.0 \%$ & $92.4 \%$ & $93.0 \%$ & $94.3 \%$ & $98.0 \%$ & $97.8 \%$ \\
\hline & 50th percentile & $93.8 \%$ & $81.8 \%$ & $93.9 \%$ & $95.4 \%$ & $94.5 \%$ & $89.8 \%$ & $80.7 \%$ & $65.3 \%$ & $65.7 \%$ & $70.1 \%$ & $96.8 \%$ & $94.9 \%$ \\
\hline & 25 th percentile & $77.9 \%$ & $100.0 \%$ & $71.4 \%$ & $90.6 \%$ & $89.7 \%$ & $80.7 \%$ & $60.3 \%$ & $100.0 \%$ & $100.0 \%$ & $100.0 \%$ & $74.3 \%$ & $74.2 \%$ \\
\hline & 10th percentile & $88.9 \%$ & $100.0 \%$ & $100.0 \%$ & $100.0 \%$ & $80.7 \%$ & $57.6 \%$ & $100.0 \%$ & $100.0 \%$ & $100.0 \%$ & $100.0 \%$ & $100.0 \%$ & $100.0 \%$ \\
\hline & 5th percentile & $100.0 \%$ & $100.0 \%$ & $100.0 \%$ & $100.0 \%$ & $100.0 \%$ & $100.0 \%$ & $100.0 \%$ & $100.0 \%$ & $100.0 \%$ & $100.0 \%$ & $100.0 \%$ & $100.0 \%$ \\
\hline
\end{tabular}


Table 15. Monthly statistics of Tappan Lake, Ohio, daily mean flow-by amounts for indicated pumping rates and target minimum flow-by amounts, expressed as a percentage of corresponding statistic based on observed outflows. - Continued

[ $\mathrm{ft}^{3} / \mathrm{s}$, cubic foot per second; Mgal/d, million gallons per day; color scale is gradient from maximum value, in green, to minimum value, in red]

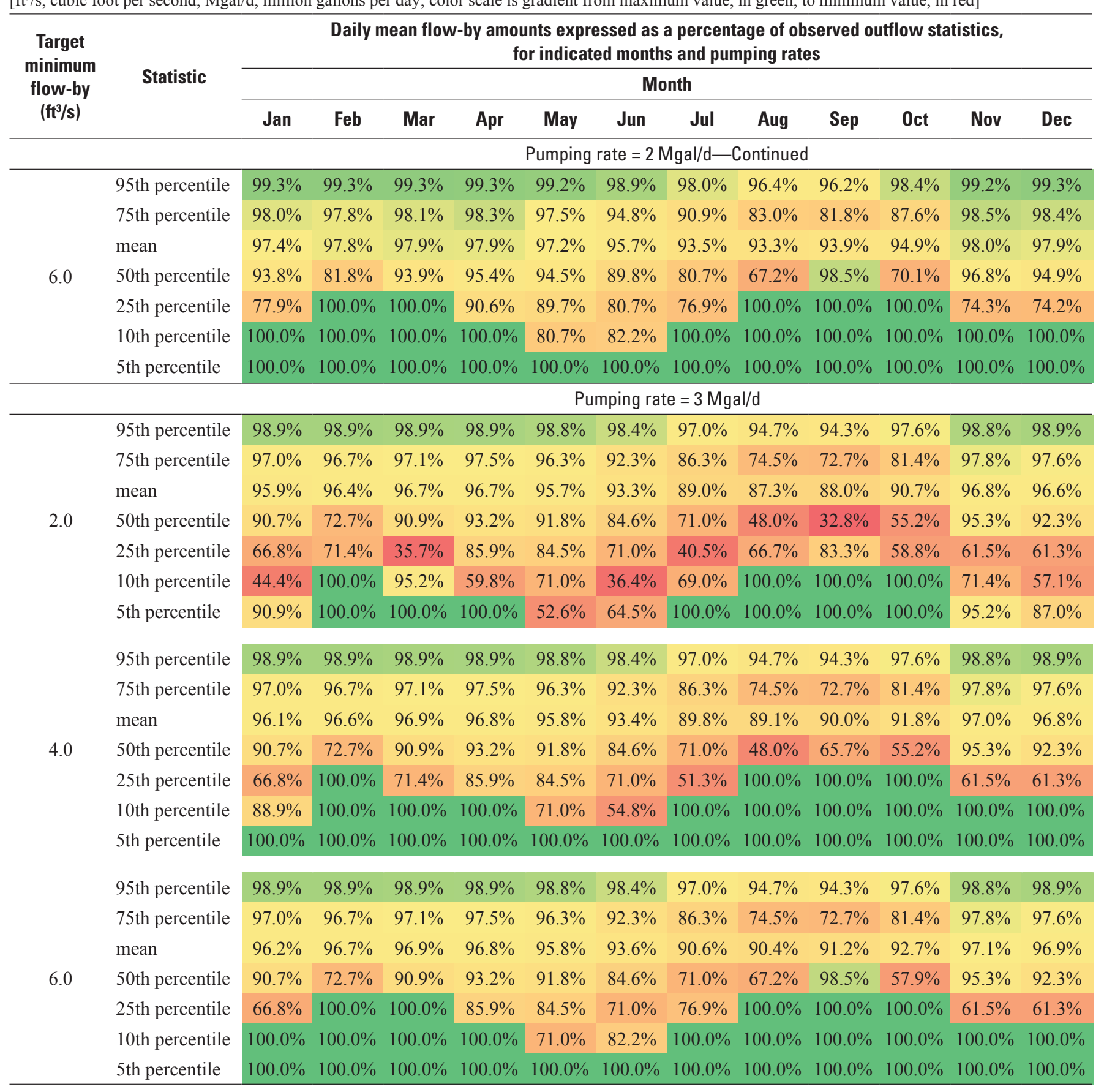




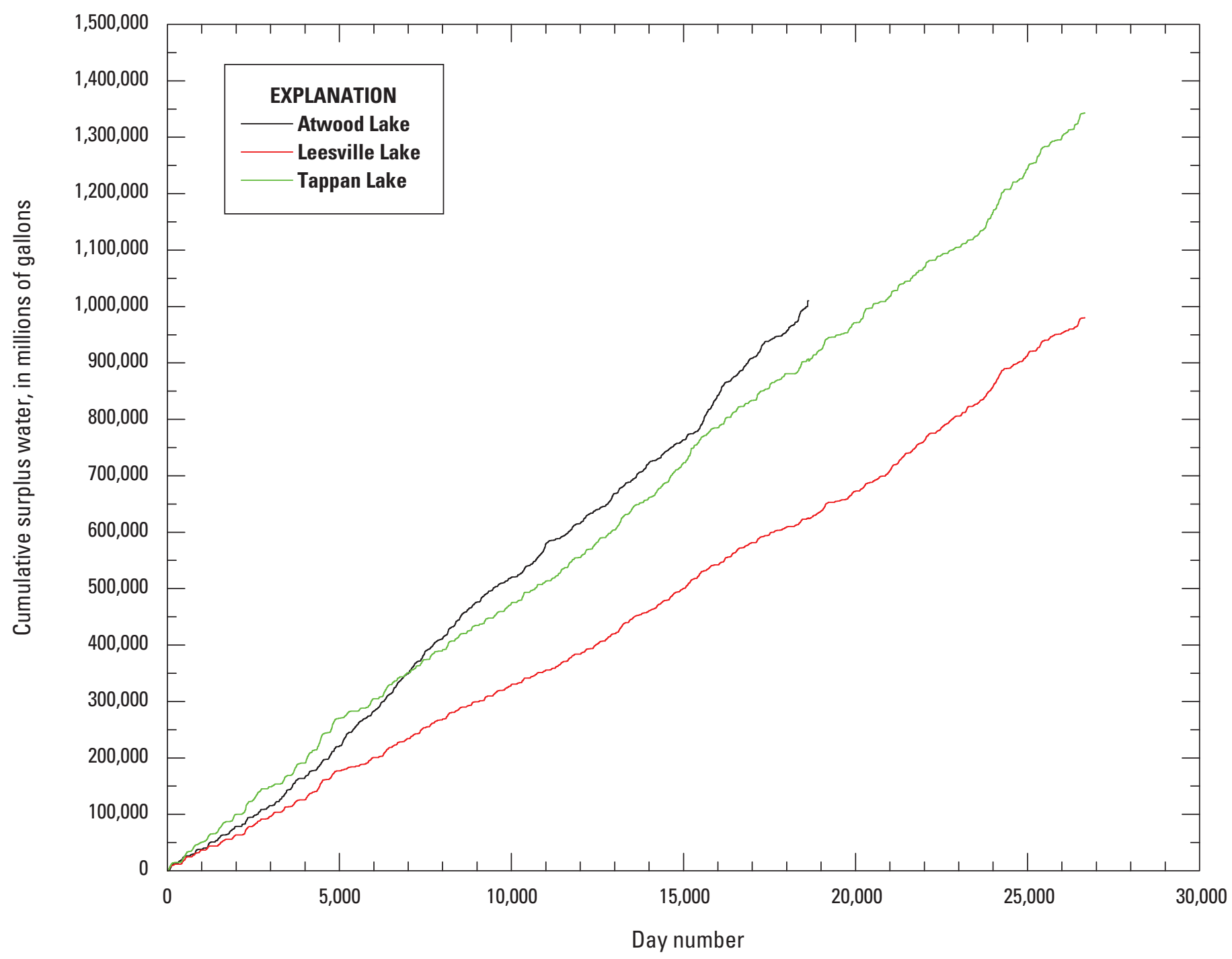

Figure 3. Graph showing surplus-water mass curves based on current target minimum outflows for the Atwood, Leesville, and Tappan Lakes in the Muskingum River Watershed, Ohio. 


\section{References Cited}

LAWriter Ohio Laws and Rules, 2000, Ohio Revised Code - Chapter 6101 - Conservancy districts, accessed February 4, 2013, at http://codes.ohio.gov/orc/6101.

Ohio Department of Natural Resources, 2011, Precipitation in Ohio: Ohio Department of Natural Resources Fact Sheet 92-11, 2 p., accessed April 29, 2013, at http://www.ohiodnr.com/portals/7/pubs/pdfs/fctsht11.pdf.

SAS Institute, Inc., 2011, Base SAS(R) 9.2 Procedures Guide-Statistical Procedures (3d ed.): The UNIVARIATE Procedure - Calculating percentiles, accessed May 15, 2010, at http://support.sas.com/documentation/ cdl/en/procstat/63104/HTML/default/viewer.htm\#procstat univariate_sect028.htm.

U.S. Army Corps of Engineers, 2005, Muskingum Basin Infrastructure Study, accessed February 4, 2013, at http://www.lrh.usace.army.mil/Portals/38/docs/CORPS_Muskingum_Infrastructure_Report_2005_.pdf.

U.S. Army Corps of Engineers, 2013a, Huntington District-Water Management-Atwood Lake, accessed February 4, 2013, at http://www.lrh-wc.usace.army.mil/wc/ atins.htm.

U.S. Army Corps of Engineers, 2013b, Huntington District-Water Management-Leesville Lake, accessed February 4, 2013, at http://www.lrh.usace.army.mil/ Missions/Recreation/Ohio/LeesvilleLake.aspx.

U.S. Army Corps of Engineers, 2013c, Huntington District-Water Management-Tappan Lake, accessed February 4, 2013, at http://www.lrh.usace.army.mil/ Missions/Recreation/Ohio/TappanLake.aspx.

\section{Glossary}

flow-by The computed net flow in the stream immediately downstream from a lake or reservoir, after accounting for withdrawals. The flow-by amount equals the outflow minus any withdrawals. Flow-by amounts are, by definition, available to support water uses downstream from the lake or reservoir.

minimum in-stream flow-target multiple A multiplier applied to established minimum in-stream flow targets to compute new hypothetical target minimum flow-by amounts.

outflow The total amount of water discharged from a lake or reservoir before withdrawals.

seasonal pool levels Target water levels for a lake or reservoir that vary as a function of season. In Ohio, winter pool levels typically are set lower than summer pool levels to facilitate greater flood control.

surplus water The lake or reservoir outflow minus the target minimum flow-by amount. Surplus water represents the amount of water that potentially is available for withdrawal while still meeting the minimum flow-by target immediately downstream from the lake or reservoir.

surplus water mass curve A curve produced by plotting the cumulative amount of surplus water as a function of time. Mass curves can be used to determine whether hypothetical water demands can be met at all times or, if not, to determine the maximum amount and duration of demand excess.

target minimum flow-by Minimum in-stream flow targets downstream from the lake or reservoir, after accounting for withdrawals. Target minimum flow-by amounts represent goals for minimum in-stream flows; however, they are not legal mandates and may not be achievable during extended low-flow periods.

withdrawals Water removed for some purpose from a lake, reservoir, or their outflows. Withdrawals are not part of the flow-by and as such are not available to support in-stream water uses downstream from the lake or reservoir. 


\section{Appendix 1.}

Table 1-1. Cumulative surplus water at the Atwood, Leesville, and Tappan Lakes as a function of target minimum flow-by amount.

This table is a separate document, available for downloading at http://pubs.usgs.gov/sir/2013/5112/. 




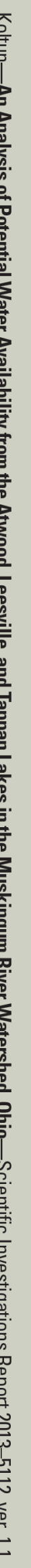

